\title{
External Debt and Macroeconomic Performance in Latin America and East Asia
}

SINCE THE ONSET of the international debt crisis in the early 1980 s, the dismal economic performance of the Latin American debtor countries has been frequently contrasted with the strong performance of their East Asian counterparts. Table 1 documents the remarkable difference. Throughout East Asia, with the exception of the Philippines, the developing countries have maintained strong growth rates and low inflation. None but the Philippines has been forced to reschedule its foreign debt. On the other hand, throughout Latin America, with the partial exception of Colombia, national incomes have grown slowly or have declined, inflation has surged, and debtors have been forced to reschedule their outstanding debts.

Many analysts have already tackled the problem of explaining why Latin America's record is so poor compared with East Asia's. Each has pointed to different "lessons" to be learned. 'Some argue that the Asian record is better because the external shocks that hit the Asian countries

I would like to thank Data Resources, Inc., for generous access to its computer facilities, Abhijit Banerjee and Nuriel Roubini for very helpful research assistance, and Jorge Dominguez and Dwight Perkins for helpful discussions. My deep intellectual debt is to the late Carlos F. Diaz-Alejandro, a dear friend and colleague, who generously introduced me to the economics of Latin America.

1. A thorough and stimulating comparison of the two regions can be found in Chingyuan Lin, "Latin America and East Asia: A Comparative Development Perspective" (International Monetary Fund, unpublished manuscript, 1985). Bela Balassa has written extensively on the patterns of adjustment in the developing countries after 1973, with an emphasis on the trade regime. That work has greatly influenced this paper. See, for example, "Adjustment Policies in Developing Countries: A Reassessment," World Development, vol. 12 (September 1984), pp. 955-72, and various references cited therein. Other studies comparing Asia and Latin America will be mentioned throughout this report. 
Table 1. Macroeconomic Performance in Latin America and East Asia, 1970-84

Percent unless otherwise specified

\begin{tabular}{|c|c|c|c|c|c|c|}
\hline \multirow[b]{2}{*}{ Country } & \multicolumn{2}{|c|}{ GDP growth } & \multicolumn{2}{|c|}{ Inflation } & \multirow{2}{*}{$\begin{array}{c}\text { Per capita } \\
\text { GDP } \\
\text { in } 1983 \\
\text { (dollars) }\end{array}$} & \multirow{2}{*}{$\begin{array}{c}\text { Year of } \\
\text { rescheduling }\end{array}$} \\
\hline & $1970-81$ & $1981-84$ & $1970-81$ & $1981-84$ & & \\
\hline \multicolumn{7}{|l|}{ Latin America } \\
\hline Argentina & 1.6 & -0.1 & 130.8 & 340.4 & $2,000^{\mathrm{a}}$ & 1984 \\
\hline Brazil & 7.6 & 0.8 & 40.5 & 142.2 & 1,618 & 1983,1984 \\
\hline Chile & 2.8 & -3.2 & 42.7 & 18.8 & 1,692 & 1983 \\
\hline Mexico & 6.7 & -0.9 & 17.5 & 74.4 & 1,901 & 1983,1984 \\
\hline Peru & 3.4 & -2.3 & 33.8 & 94.0 & 870 & 1983,1984 \\
\hline Venezuela & 3.7 & -2.2 & 9.1 & 9.3 & 4,124 & 1984 \\
\hline Weighted average & 5.6 & -0.4 & 46.3 & 137.9 & 1,992 & $\ldots$ \\
\hline Colombia & 5.2 & 1.7 & 21.7 & 20.1 & 1,399 & $\ldots$ \\
\hline \multicolumn{7}{|l|}{ East Asia } \\
\hline Indonesia & 8.0 & 4.3 & 17.0 & 10.6 & 501 & $\ldots$ \\
\hline Korea & 8.1 & 7.6 & 16.7 & 4.3 & 1,923 & $\ldots$ \\
\hline Malaysia & 7.8 & 6.2 & 6.2 & 4.5 & 1,971 & $\ldots$ \\
\hline Thailand & 7.1 & 5.3 & 10.0 & 3.3 & 812 & $\cdots$ \\
\hline Weighted average & 7.8 & 5.8 & 14.4 & 6.5 & 1,197 & $\ldots$ \\
\hline Philippines & 5.9 & -0.6 & 13.5 & 22.2 & 665 & 1984 \\
\hline
\end{tabular}

Sources: Gross domestic product (GDP) is from Data Resources, Inc. (DRI), International Data Base, based on country sources. Inflation is the annual average rate between the dates shown, based on the consumer price index from International Monetary Fund, International Financial Statistics. Per capita GDP is calculated by converting local currency GDP for 1983 by the average official exchange rate for the year. The rescheduling dates are from World Bank, World Development Report 1985 (World Bank, 1985), p. 28 . In this and subsequent tables, regional averages are based on GDP shares for 1975-80.

a. Preliminary.

in the early 1980s were less severe than those that buffeted Latin America. ${ }^{2}$ Others suggest that the Latin American countries simply overborrowed. ${ }^{3}$ Some analysts, particularly Bela Balassa and Anne Krueger, point to exchange rate management and the trade regime as being crucial. Supply-siders contend that the Asian economies have flourished under lower tax rates, and many other economists join them in arguing that the Asian economies have been market-oriented, while the Latin American economies have not.

The available empirical evidence can help to discriminate among

2. For an example of this point of view, see Robert Solomon, "Brazil vs. Korea: Differing Experiences as Debtors," International Economic Letter (Washington, D.C.: RS Associates, Inc., November 12, 1984).

3. This appears to be the view of Lance Taylor in "The Theory and Practice of Developing Country Debt: An Informal Guide for the Perplexed"' (Massachusetts Institute of Technology, 1985). 
these alternative views. Several do not hold up. As I argue below, "success" or "failure" in economic performance in the 1980s does not seem to be importantly tied to the size of external shocks. Many nations suffering economic failure, such as Mexico and Venezuela, had rising terms of trade in the period 1975-83, while many of the successful Asian economies suffered severe declines in their terms of trade. Nor was the extent of foreign borrowing consistently higher in Latin America than in Asia. Relative to gross domestic product (GDP), Korea and Thailand ran current account deficits in the 1970s that were as large or larger than the deficits in Latin America. By 1981, on the eve of the debt crisis, Korea's debt-GDP ratio was higher than Brazil's. Too, the extent of government involvement in the economy appears to be as great in Asia as in Latin America. Trade policies in most Asian countries, while export-promoting, were certainly not laissez-faire. State enterprises have played a large role in many Asian economies, as they have in Latin America. Taxes as a percentage of GDP are not significantly different, on average, in Asia and Latin America, and many of the successful Asian economies have tax revenues that are higher, as a proportion of total income, than those of many of the "failures" in Latin America.

The more important differences seem to center on exchange rate management and on the trade regime. Latin American and Asian borrowers have differed not only in the amounts borrowed, but also in the uses to which the loans were applied. Simply put, the Latin American countries did not use the foreign borrowing to develop a resource base in tradable goods, especially export industries, adequate for future debt servicing. While current account-GDP ratios developed commensurately in the two regions, debt-export ratios and debt service to export ratios diverged markedly. This divergence occurred for two main reasons. First, exports grew more rapidly in Asia than in Latin America, and indeed export growth in Asia dramatically outstripped GDP growth. In 1965, the share of exports in GDP was comparable in the two regions. By 1980, the export-GDP ratios in Asia were far higher than those in Latin America. Second, overvalued exchange rates in Latin America encouraged capital flight. Foreign borrowing by Latin American governments (particularly Argentina, Mexico, and Venezuela) often went to finance the private sector's accumulation of foreign assets, rather than an increase in export capacity.

The foundations for export-promotion policies in Asia and for import- 
substitution policies in Latin America are political. It is crucial to understand the political economy of export promotion in order to understand the continuing paralysis of the Latin American economies. In spite of an urgent need to spur exports to grow out of the debt crisis, movements toward export promotion in almost every Latin American country have been frustrated recently by countervailing movements toward further protection of domestic industry. Currency devaluations that might help exporters have been accompanied by discounts of the national currencies in black markets. The sharp divergences of the official and black market rates, which have not occurred in Asia, often represent an implicit tax on exporters, as I describe below. The debate within Latin America over whether to repudiate or repay the debt really involves two debates: one between the country and the foreign commercial banks over the terms of debt repayment; and one within the country, between export interests on one side and political interests tied to the current import-substitution regimes on the other.

This report is divided into three sections. In the first, I examine some of the leading hypotheses concerning the Latin American-East Asian economic record and show the importance of export growth in explaining the differential performance of the two regions. In the second section, I speculate on some of the political developments that turned the Asian economies toward export promotion and the Latin American countries toward import substitution. The third section looks briefly at the current political economy of trade in Latin America to show how political paralysis is contributing to the continued economic paralysis.

\section{Explanations for Performance in East Asia and Latin America}

The debt crisis of the early 1980s was triggered by a combination of global economic events and domestic developments in the debtor countries. The best evidence for the contribution of global events is the simultaneous onset of the crisis in more than forty developing countries. The best evidence for the role of distinctively national developments is the success of many debtor countries in surmounting the external shocks without an emergency debt rescheduling. As already indicated in table 1, the Latin American countries rescheduled, while the East Asian countries, by and large, did not. 
Table 2. Terms-of-Trade Shock, 1979-83a

\begin{tabular}{|c|c|c|c|}
\hline Country & $\begin{array}{l}\text { Percentage } \\
\text { change in } \\
\text { terms of trade } \\
\text { from } 1975-78^{\mathrm{b}} \\
\quad(1)\end{array}$ & $\begin{array}{c}\text { Import share as } \\
\text { percentage of } \\
G D P, 1975-78 \\
\text { average } \\
\text { (2) }\end{array}$ & $\begin{array}{c}\text { Real income effect } \\
\text { of terms-of-trade } \\
\text { change } \\
(3)=(1) \times(2) / 100\end{array}$ \\
\hline \multicolumn{4}{|l|}{ Latin America } \\
\hline Argentina & 3 & $5.4^{\mathrm{c}}$ & 0.2 \\
\hline Brazil & -29 & 7.8 & -2.3 \\
\hline Chile & -27 & 17.7 & -4.9 \\
\hline Mexico & 26 & 7.1 & 1.8 \\
\hline Peru & -22 & 16.3 & -3.7 \\
\hline Venezuela & 64 & 24.9 & 15.9 \\
\hline Weighted average & 1.1 & 9.5 & 1.2 \\
\hline Colombia & -18 & 10.7 & -2.0 \\
\hline \multicolumn{4}{|l|}{ East Asia } \\
\hline Indonesia & 36 & 17.2 & 6.1 \\
\hline Korea & -3 & 29.6 & -0.9 \\
\hline Malaysia & 14 & 35.3 & 4.9 \\
\hline Thailand & -14 & 20.4 & -2.9 \\
\hline Weighted average & 11.8 & 24.0 & 2.1 \\
\hline Philippines & -16 & 20.1 & -3.2 \\
\hline
\end{tabular}

Sources: For Brazil, Colombia, Korea, Malaysia, Thailand, and the Philippines, export and import unit value indexes are taken from IMF, International Financial Statistics. For Chile, Peru, Venezuela, and Indonesia, the terms of trade for 1975-81 are taken from World Bank, World Debt Tables, several issues, and then spliced with data for 1982-83 from World Bank, World Development Report 1984 and 1985 (World Bank, 1984 and 1985), table 9. For Argentina, the data are from the World Bank. For Mexico, export and import price indexes are calculated as ratios of nominal values to real values (goods and services). Data are from Mexican National Accounts. The import share in GDP is calculated as the average ratio of merchandise imports to GDP for 1975-78, using data from IMF, International Financial Statistics.

a. The terms of trade measure the price of exports relative to imports.

b. Percentage change in average terms of trade of 1979-83 relative to average of 1975-78.

c. $1976-78$.

\section{THE ROLE OF EXTERNAL SHOCKS}

The simplest explanation for the differences in performance is that the global shocks hit the Latin American countries with greater force. Two possibilities are often raised: first, that the commodity terms of trade deteriorated more sharply in Latin America than in Asia, and, second, that the Latin American countries had a higher proportion of debt in variable interest rate loans, and thus felt the effect of rising interest rates sooner. These hypotheses are considered in tables 2 and 3.

The first column of table 2 shows the change in the terms of trade of the two regions during 1979-83, compared with 1975-78. On a weighted average basis (all regional averages shown throughout the paper are 


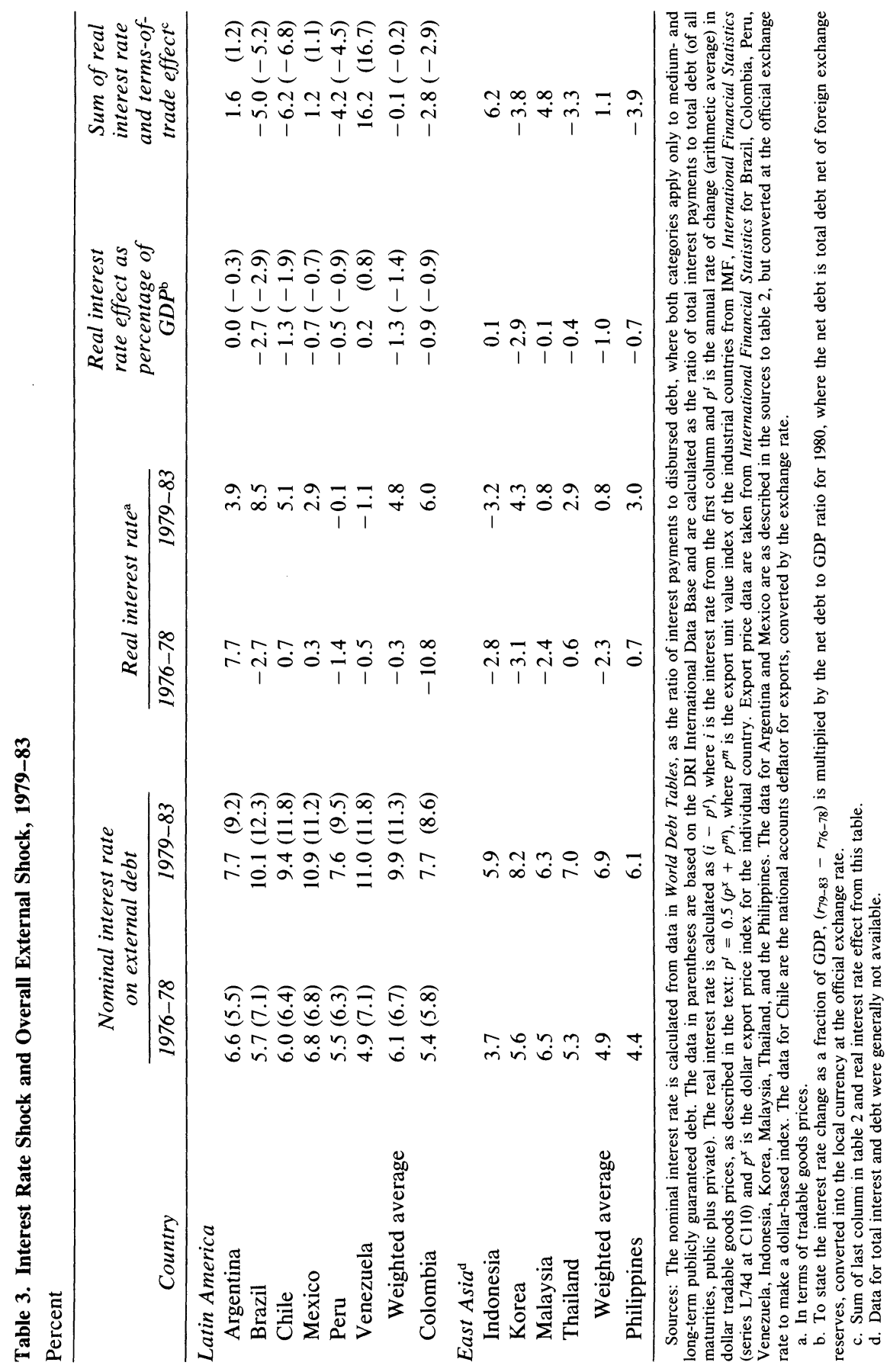


based on GDP weights for 1975-80), ${ }^{4}$ the terms of trade actually rose in both regions, but less sharply in Latin America than in Asia. Clearly, the terms of trade do not well explain "success" and "failure" in handling external debt in the early 1980s, since three of the six crisis cases in Latin America enjoyed terms-of-trade gains, while two of the four successful adjusters in Asia had terms-of-trade declines. The improvement in Latin America is not surprising, in view of the fact that Mexico and Venezuela are major oil exporters, while Argentina and Peru also export oil (the terms of trade for all of these countries except Peru improved during 1979-83). In Asia, Indonesia is a major oil exporter. Although real oil prices fell in 1982-83, the decrease was not nearly as large as the increase of the preceding four years. Note that the terms-of-trade experience of Colombia was below the Latin American average.

In the third column of the table, the terms-of-trade effect is measured as a share of GDP by multiplying the change in the terms of trade across the two periods by the average import share of GDP for each economy (shown in the second column). The product of the terms-of-trade change and the import share is an approximate measure of the real income effect, expressed as a percentage of GDP, of the terms-of-trade change. Brazil, Chile, and Peru fit the common perception that the Latin debtors suffered serious income losses from terms-of-trade declines. In each case the losses exceed 2 percent of GDP each year. On the other hand, Mexico and Venezuela enjoyed significant terms-of-trade improvements.

These results are a bit surprising, but they are consistent with the findings of Donal Donovan and Nuriel Roubini, who have compared the magnitude of terms-of-trade shocks for a much larger sample of middleincome developing countries. ${ }^{5}$ Both authors found that the magnitude of terms-of-trade movements was not markedly different for groups of reschedulers and nonreschedulers. It should be noted that while the

4. The GDP weights are as follows. In Latin America: Argentina, 0.171 ; Brazil, 0.385 ; Chile, 0.039; Mexico, 0.278; Peru, 0.028; Venezuela, 0.099. In East Asia: Indonesia, 0.381; Korea, 0.327; Malaysia, 0.121; Thailand, 0.171. Note that Colombia and the Philippines are not included in the regional averages.

5. See Donal J. Donovan, "The Sources of External Debt Servicing Difficulties: Some Empirical Evidence," DM/84/15 (International Monetary Fund, Exchange and Trade Relations Department, March 1984); and Nuriel Roubini, "The Origins and Causes of External Debt Servicing Difficulties,"' S-I paper (International Monetary Fund, August 1985). 
cumulative terms-of-trade movements during 1978-83 were comparable for the two groups, Roubini shows that for the rescheduling group, the terms of trade improved more during 1977-81 and then fell more during 1981-83 than it did for the nonreschedulers. This finding seems to hinge on the heavy representation of oil exporters in the rescheduling group.

The second external shock of this period was the sustained rise in U.S. interest rates that began at the end of 1979. Higher interest rates affected not only the costs of new borrowing, but also the interest charges on existing debt, since a significant fraction of LDC debt was contracted at variable interest rates. Typically, syndicated commercial bank loans tie interest payments to a short-term dollar rate, such as the London interbank offer rate (LIBOR) or the U.S. prime rate, on a quarterly or semiannual basis. The extent of borrowing at variable interest rates differs widely across debtor countries. It is much higher in Latin America than in Asia (with the exception of Korea), since a higher fraction of the Asian debt is nonbank borrowing, originating instead from official creditors such as export credit agencies of the developed countries.

The implicit nominal interest rate paid by the various countries can be calculated by dividing total interest payments in any year into the total stock of debt. Ideally this should be done for a comprehensive measure of the debt stock, but given the poor quality of the available data, it can be done consistently only for the medium- and long-term publicly guaranteed debt of each country, as reported by the World Bank. Such implicit rates are shown in the first two columns of table 3. Note that interest rates rise by at least 3 percentage points in Brazil, Chile, Mexico, and Venezuela, but rise by much smaller magnitudes in Asia. This reflects the higher proportion of commercial bank loans in the Latin American debt stocks. Peru and Colombia both rely heavily on official credits, often at concessional rates, and therefore show lower and less variable interest rates than do the other countries in the region.

For the Latin American countries and for Korea, it is possible to calculate effective interest rates on a more comprehensive basis, including non-publicly guaranteed long-term debt and debt with original maturity of less than one year. These more comprehensive rates are shown in parentheses in the table. Since most of the private debt and short-term debt is at nonconcessional rates, and therefore closely tied to short-term U.S. rates, the rise in the more comprehensive measure is generally greater (though not so in Venezuela). 
What counts in terms of debt servicing burden, of course, is the real interest rate, rather than the nominal interest rate. It is a matter of some delicacy as to how to define the relevant real rate (ex ante versus ex post, and according to which inflation measure), and various theoretical derivations suggest different approaches.$^{6}$ As a pragmatic procedure, I measure the real interest rate burden relative to the (ex post) rate of increase of dollar tradable goods prices in each country. In principle, tradable goods prices should be measured as a weighted average of export prices and the prices of import-competing sectors. Since the latter prices are not directly observable, I use an average export price index of the developed economies as a measure of the import-competing prices for each of the debtor countries. For each country, the annual percentage change in dollar tradable goods prices, $p^{t}$, is measured as $0.5\left(p^{x}+p^{m}\right)$, where $p^{x}$ is the export price index of the country, and $p^{m}$ is the proxy for import-competing prices. The real interest rate is then $i-p^{t}$. This own real rate of interest measure can be considered as exogenous to the country in question, and increases in the real rate constitute an external shock to the country.

The real rate measures are shown in the third and fourth columns of table 3, and are based on the nominal interest rates from the first and second columns. In some oil-exporting countries, real interest rates actually fall in 1979-83 relative to 1976-78, since the dollar export prices rise more rapidly. Brazil and Korea are the only two countries to show very large increases in real interest rates, since only these countries had large increases in nominal interest rates combined with falling export prices.

To measure the interest rate shock as a proportion of GDP, I multiply the change in the real interest rate across the two periods by a debt-GDP ratio. An ideal measure would require a comprehensive accounting of the country's foreign assets (reserves, capital flight, and so forth) as well as debts, and apply relevant interest rate changes to each class of asset and debt. Without much better data, that procedure is not possible, so I fall back on a cruder measure. The foreign exchange reserves of the country are subtracted from a gross debt measure, and this net debt is

6. For two examples of theoretically derived measures of the interest burden, see Rudiger Dornbusch, "Policy and Performance Links between LDC Debtors and Industrial Nations," BPEA, this issue; and Warwick McKibbin and Jeffrey Sachs, "Macroeconomic Policies in the OECD and LDC External Adjustment," Working Paper 1534 (National Bureau of Economic Research, 1985). 
taken as a fraction of GDP for the year 1980. The change in real interest rates is then multiplied by this ratio, with the results shown in column 5 (numbers in parentheses are calculated based on the more comprehensive interest rate series). Note that the real interest rate shock is large and negative only for Brazil, Chile, and Korea. ${ }^{7}$

In the final column of the table the terms-of-trade and interest rate shocks are combined. The inescapable conclusion is that macroeconomic performance and the need to reschedule are not closely tied to the magnitude of the external shocks as a proportion of GDP. Argentina, Mexico, and Venezuela had positive (that is, beneficial) net shocks. Korea and Thailand, on the other hand, had very large negative shocks relative to GDP, but both maintained strong economic performance. Part of the answer to this puzzle, we shall see, is that in Latin America, the debt servicing burden became very large as a fraction of exports, though not necessarily large relative to GDP.

\section{THE EXTENT OF FOREIGN BORROWING}

It might be supposed that the Latin American debtors have suffered far more because they borrowed far more during the 1970s. Consider first the cumulative current account deficit for the various countries. In a given year, the current account deficit equals the increase in a country's net liabilities to foreigners, subject to an adjustment for capital gains and losses on preexisting stocks of assets and liabilities. The cumulative deficit for the decade should then approximately equal the increase in the country's net liabilities over the course of the decade. As shown in table 4 , column 1 , there is a large variation in the extent of net borrowing in both regions, and on average the Latin American countries borrowed only slightly more. The variation in net borrowing within each region, compared with the uniformity of results, is striking. In Latin America, Venezuela ran a cumulative current account surplus, and Argentina and Colombia were approximately in balance. The remaining countries ran sizable cumulative deficits. In Asia, Indonesia and Malaysia maintained

7. With an alternative real interest rate measure, such as the nominal interest rate minus U.S. inflation, the real interest rate shock is negative for all countries, but of modest magnitude. At the peak, the measured U.S. real interest rate rises by about 10 percentage points and is multiplied by a debt-GDP ratio on the order of 20 percent, producing a peak annual loss of about 2 percent of GDP and an average annual loss of about 1 percent of GDP. 
Table 4. External Debt Indicators, 1981 and $1980-83^{a}$

Percent

\begin{tabular}{|c|c|c|c|c|}
\hline Country & $\begin{array}{c}\text { Cumulative } \\
\text { current } \\
\text { account } \\
\text { deficit, } \\
\text { 1970-80 } \\
\text { (percentage of } \\
\text { 1981 GDP) }\end{array}$ & $\begin{array}{c}\text { Debt-GDP } \\
\text { ratio, } \\
1981\end{array}$ & $\begin{array}{l}\text { Debt-export } \\
\text { ratio, } 1981\end{array}$ & $\begin{array}{c}\text { Debt service } \\
\text { ratio, } \\
1980-83\end{array}$ \\
\hline \multicolumn{5}{|l|}{ Latin America } \\
\hline Argentina & 2.3 & 31.6 & 334.7 & 214.9 \\
\hline Brazil & 22.8 & 26.1 & 298.7 & 132.6 \\
\hline Chile & 19.8 & 47.6 & 290.0 & 153.3 \\
\hline Mexico & 13.9 & 30.9 & 258.8 & 161.8 \\
\hline Peru & 19.3 & 44.7 & 223.5 & 122.2 \\
\hline Venezuela & -7.5 & 42.1 & 134.0 & 117.8 \\
\hline Weighted average & 13.6 & 31.3 & 271.5 & 153.8 \\
\hline Colombia & 0.4 & 21.9 & 182.9 & 103.8 \\
\hline \multicolumn{5}{|l|}{ East Asia } \\
\hline Indonesia & 0.6 & 24.1 & 87.1 & n.a. \\
\hline Korea & 24.6 & 27.6 & 76.6 & 90.1 \\
\hline Malaysia & -2.0 & 27.8 & 51.8 & 16.9 \\
\hline Thailand & 22.4 & 25.7 & 103.1 & 58.1 \\
\hline Weighted average & 11.9 & 25.9 & 82.1 & 61.7 \\
\hline Philippines & 18.3 & 40.6 & 214.6 & 152.7 \\
\hline
\end{tabular}

Sources: Debt stocks are from the DRI International Data Base. The cumulative current account deficit is computed from International Financial Statistics data and is divided by the GDP of the country measured at the official exchange rate. Exports are from the national income account series for exports of goods and services of International Financial Statistics.

n.a. Not available.

a. The debt service ratio equals total debt servicing expenditures relative to exports. Debt servicing equals interest payments on all debt, plus amortization of principal on medium- and long-term debt, plus the stock of short-term debt (the principal of which, by definition, comes due within the year). Debt stocks are end-of-year total gross debt.

approximate balance, while Korea ran up a larger proportionate deficit than did any of the other countries in Asia or Latin America. Thailand and the Philippines also ran large current account deficits in the 1970s. It is certainly hard to see a strong link between the size of a nation's current account deficit and whether it suffers a debt crisis.

The accumulation of gross external debt can exceed the current account deficit if the private sector accumulates foreign assets. ${ }^{8}$ One typical situation is that the private sector converts domestic assets into

8. Given the definition of debt that is used in this table and in other discussion of the debt crisis, there are several points of slippage between current account deficits and debt accumulation. Debt is generally defined as including only fixed-income securities, not equities or foreign direct investment. Thus, a current account deficit that is financed by foreign direct investment would not be associated with any increase in "debt" as it is 
foreign assets in expectation of a devaluation. The central bank supports the domestic currency, before the devaluation actually takes place, by selling the foreign assets to the private sector. In many, though not all, Latin American countries, gross debt accumulation was in fact substantially above the cumulative current account deficit, particularly in the period 1978-82, as is evident from a comparison of the first and second columns of the table. Note, for example, that in Argentina, Mexico, Peru, and Venezuela, the gross debt, which could not have been large relative to 1981 GDP before 1970 , is vastly larger than the cumulative current account deficits for the decade of the 1970s. Independent evidence, marshaled by me and by others, has shown that these countries indeed experienced enormous, though difficult to measure, capital flight in the late 1970s and early 1980s. ${ }^{9}$ The table also provides evidence of capital outflow from Indonesia, Malaysia, and the Philippines, though little capital outflow from Korea and Thailand. In the case of Indonesia and Malaysia, much of that outflow appears to be the routine repatriation of overseas Chinese profits to Hong Kong and Singapore. In the case of the Philippines, there was a significant flight of capital in the wake of the political and economic upheaval caused by the Aquino assassination.

The accumulation of gross debt is a reflection both of current account deficits and of capital flight. As shown in table 4, the Latin American countries in fact accumulated slightly more debt, as a proportion of GDP, than did the Asian nations. The difference becomes much more significant only when debt is expressed as a percentage of exports, as in column 3. The higher ratio of debt to exports is most likely the critical factor in making Latin America so vulnerable to the external shocks of the early 1980s.

The contrast between the two regions becomes decisive when the debt service to export ratios are compared in column 4 . The debt service measure is taken at its most comprehensive level: interest payments on

typically measured. Second, the debt is measured gross, rather than net. Thus, debt can rise even with current account balance and no increase in private sector holdings of foreign assets if the government uses the foreign borrowing to accumulate official foreign exchange reserves.

9. See, for example, my comments on Carlos F. Diaz-Alejandro, "Latin American Debt: I Don't Think We Are in Kansas Anymore,"' BPEA, 2:1984, pp. 335-403. Direct evidence for capital flight is found in the increase in U.S. bank liabilities to Latin American residents during 1979-82. Such a large increase is not apparent for the Asian economies. See also "Latin America: The Other Side of Debt," Economist, June 23, 1984, pp. 73-74. 
debt of all maturities, plus amortization of principal on medium- and long-term debt, plus complete repayment of all short-term debt. The results are striking, in that in Latin America, debt servicing requirements exceeded total exports, on average, in the years 1980-83, while in Asia (with the notable exception of the Philippines), the debt servicing was well below the level of exports. The higher ratio in Latin America is due to a combination of factors already discussed: higher debt-export ratios; a higher concentration of debt in short maturities; and a higher effective interest rate on the debt, because of its concentration in variable interest rate bank claims rather than fixed interest rate official credits.

With debt servicing ratios above 100 percent, it was impossible for the Latin American countries to service their debts fully when new lending dropped off in 1982. Debt reschedulings became inevitable. The slowdown in lending itself resulted from several factors: concern over economic mismanagement in the debtor countries; tight monetary conditions in the creditor countries; and the self-fulfilling fragility of the Latin American debt structure in light of the extraordinary debt service ratios. When each lender recognizes that a country will be unable to service its debt if the other lenders stop making loans, a "panic" or "run" on the country becomes possible, as each lender attempts to take out its assets ahead of the other claimants. ${ }^{10}$ With debt service ratios in excess of 100 percent, it is easy to see how such a run can occur.

TRADE POLICIES AND EXCHANGE RATE MANAGEMENT

Models of optimal borrowing show that capital-scarce developing countries can profitably borrow over the long term, but only if the borrowed resources are invested sufficiently in the tradable goods that ultimately will be used to service the accumulated foreign debt. (Borrowing in the short run can be fruitful for smoothing consumption over time in the face of temporary external shocks, even if the borrowed funds are not used to augment investment in tradables.) ${ }^{11}$ Over time, as debt is

10. For a formal analysis of a "panic," see Jeffrey Sachs, "Theoretical Issues in International Borrowing," Princeton Studies in International Finance 54 (Princeton University, International Finance Section, 1984).

11. For a theoretical discussion of optimal borrowing that details the role of tradables versus nontradables and the role of consumption versus investment, see Richard N. Cooper and Jeffrey D. Sachs, "Borrowing Abroad: The Debtor's Perspective," in Gordon W. Smith and John T. Cuddington, eds., International Debt and Developing Countries (World Bank, 1985), pp. 21-60. 
accumulated, the price of tradable goods should rise relative to nontradable goods, to encourage the movement of resources into the tradable goods sectors. Moreover, investment in tradables should be in sectors that are profitable when outputs and inputs are evaluated at world prices, rather than tariff-distorted prices. In a classic paper, Richard Brecher and Carlos Diaz-Alejandro showed that national income will decline when foreign capital inflows are attracted by high rates of return that are induced by tariff protection. ${ }^{12}$ The following evidence suggests that the Latin American economies have violated both dicta in recent years.

It is not easy to get good measures of the size of the tradables sectors over time. Trade data reveal the extent of actual trade, not the value, at world prices, of production in internationally traded commodities. Moreover, without intensive development of sector-level data, it is not possible to evaluate the returns, at world market prices, of investments in various sectors of an economy. The typical recourse, as in the first three columns of table 5 , is simply to measure the extent of actual exports relative to total income to get an estimate for the growth of the tradables sector. Though admittedly imperfect, the data strongly indicate the rapid growth of exports relative to GDP in East Asia since 1965, compared with a fairly flat pattern in Latin America. In 1965, the Korean exportGDP share was only 9 percent, the Indonesian share 5 percent, evidence that the recent high openness of these countries is a development of the past two decades, rather than a fixed feature of the economies. By 1983, the large debtor countries in Latin America (Argentina, Brazil, and Mexico) had a significantly smaller export base relative to GDP than did the Asian countries.

Another rough indicator of the extent of the tradables sector can be gleaned from data that divide production and employment into agriculture, industry, and services. The tradables sector is often loosely equated with agriculture and industry, the nontradables sector with services. In the absence of extensive trade barriers, this division is plausible. (In cases where industry is heavily protected, some industrial sectors will be counted as tradable even though their outputs are not in competition with imported goods from abroad, and their output prices are substantially above world market levels, a practice that makes the traditional

12. See Richard A. Brecher and Carlos F. Diaz-Alejandro, "Tariffs, Foreign Capital and Immiserizing Growth," Journal of International Economics, vol. 7 (November 1977), pp. 317-22. 
Table 5. Comparisons of Industrial Structure, Selected Years

Percent

\begin{tabular}{|c|c|c|c|c|c|c|}
\hline \multirow[b]{2}{*}{ Country } & \multicolumn{3}{|c|}{ Share of exports in GDP } & \multicolumn{3}{|c|}{$\begin{array}{l}\text { Share of labor force } \\
\text { in services }\end{array}$} \\
\hline & 1965 & 1983 & Change & 1965 & 1981 & Change \\
\hline \multicolumn{7}{|l|}{ Latin America } \\
\hline Argentina & 8 & 13 & 5 & 48 & 59 & 11 \\
\hline Brazil & 8 & 8 & 0 & 34 & 46 & 12 \\
\hline Chile & 14 & 24 & 10 & 53 & 62 & 9 \\
\hline Mexico & 9 & 20 & 11 & 29 & 38 & 9 \\
\hline Peru & 16 & 21 & 5 & 31 & 41 & 10 \\
\hline Venezuela & 31 & 26 & -5 & 46 & 55 & 9 \\
\hline Weighted average & 11 & 15 & 4 & 37 & 47 & 11 \\
\hline Colombia & 11 & 10 & -1 & 35 & 53 & 18 \\
\hline \multicolumn{7}{|l|}{ East Asia } \\
\hline Indonesia & 5 & 25 & 20 & 20 & 30 & 10 \\
\hline Korea & 9 & 37 & 28 & 29 & 37 & 8 \\
\hline Malaysia & 44 & 54 & 10 & 27 & 34 & 7 \\
\hline Thailand & 18 & 22 & 4 & 13 & 15 & 2 \\
\hline Weighted average & 13 & 32 & 19 & 23 & 30 & 8 \\
\hline Philippines & 17 & 20 & 3 & 27 & 37 & 10 \\
\hline
\end{tabular}

Source: World Development Report 1985, tables 5 and 21.

division less useful.) Columns 4-6 show the evolution of the labor force in the service sector for the two regions. The data suggest that the Latin American countries have a much larger service sector, and hence presumably a much larger nontraded goods sector, than do the Asian economies, and that the growth of the service sector since 1965 has been faster in Latin America (11 percentage points on a weighted average basis) than in East Asia (8 percentage points). It is important to remember, however, that these data likely understate the differences in the two regions by counting heavily protected Latin American industries as part of the tradables base of the economy.

The allocation of resources between tradables and nontradables depends on trade policies, exchange rate management, and aggregate demand management. In considering the relative contribution of each, it is important to work within a framework of at least three sectors: importables, exportables, and nontradables. The three-sector framework helps to guard against an unnecessary and incorrect simplification that is present in the standard two-sector (exportable and importable) 
model of international trade. In the two-sector model, all policies that protect the import-competing sector necessarily hurt the exporting sector. Protectionism is anti-export biased, since resources pulled into importables must come from exportables. In the three-sector framework, it is immediately evident that protectionist policies can go hand in hand with export-promoting policies if resources are drawn from nontradables into both the tradable sectors. In fact, the export-promotion policies of Korea, Japan, and to a lesser extent Indonesia have had this character: exports have grown rapidly at the same time that import-competing sectors have been protected. In Latin America, on the other hand, the more traditional anti-export bias of protectionism has been present. The combination of expansionary demand policies, protected import-competing sectors, and overvalued currencies has meant that both importables and nontradables have benefited at the expense of exportables. Since the history of the long-term trade policies in the two regions is well documented, exchange rate management dominates the discussion that follows. ${ }^{13}$

The management of exchange rates, like the management of trade policies, can have complex and differential effects on all three sectors, particularly if there are multiple exchange rates or a significant black market premium on the purchase of foreign exchange. The simplest case is a currency with a unified and fixed exchange rate that is freely convertible on current account transactions, so that no black market for current transactions exists. Suppose that, starting from an initial zero overall balance of payments, a government initiates a money-financed fiscal expansion. The expansion will tend to worsen both the current and capital accounts, and will therefore put downward pressure on the currency. The central bank will be forced to sell foreign exchange reserves to stabilize the rate. At the same time, nontradables prices will rise under the pressure of increased demand, while tradables prices will be held down by foreign competition (importable sectors protected by quota restrictions will behave effectively as nontradables, and should be classified as such). The real value of the currency, measured as the

13. All studies have confirmed the anti-export bias of trade policies in Latin America relative to Asia. The classic study is Bela Balassa and associates, Development Strategies in Semi-Industrial Economies (Johns Hopkins University Press, 1982). See also Chingyuan Lin, "Latin America and East Asia," for a comprehensive treatment of the evidence on effective protection in several Latin American and Asian economies. 
foreign consumer price level converted by the exchange rate relative to domestic consumer prices, will tend to appreciate. Resources will be pulled into the nontradable sector and out of both of the tradables sectors. In addition, nontradables profitability will rise, the real consumption wage of urban workers will likely increase, and tradables profitability will decline. The political battle over whether to restrain demand and devalue the currency will pit urban workers and businesses in nontradables and quota-protected sectors against firms and workers (assuming they are only semimobile) in sectors exposed to international competition, such as agriculture and manufacturing exporters.

The situation is more complicated when the central bank is not only unwilling or unable to sell reserves in order to peg the exchange rate, but also unwilling to change the official parity. In such a case, the currency becomes partially inconvertible on current account transactions, since the central bank must ration the sale of foreign exchange at the official exchange rate. In such a system, exporters are typically obligated to sell their foreign exchange earnings at the official price to the central bank within a limited period. The central bank then resells these export proceeds, plus a policy-determined level of reserves, to importers at the official parity. Those individuals and firms at the front of the central bank queue are able to get the foreign exchange at the official price; individuals and firms at the end of the queue are rationed, and are typically forced to turn to an illegal black market or a legal parallel market, in which foreign currencies sell at a premium relative to the official rate. (I will henceforth use the term "black market" for this side market, though in many countries this market is either partially or wholly legal.)

A crucial question in such a system is whether the official rate or the black market rate represents the marginal cost of funds for a given class of imports. For example, if all pharmaceuticals can automatically be imported at the official rate, then the official rate will be the marginal cost of foreign exchange. On the other hand, if spare parts must be bought using black market funds, then the black market price will be the marginal cost of funds. In some cases, the black market is used only for capital account transactions, with foreign exchange being freely available at the official parity for all or most current account transactions. More commonly, though, a wide range of imports, and often imports across the board, must be purchased at the margin using black market funds. 
Domestic prices of importables then rise above world market prices converted to domestic currency units at the official, but unavailable, exchange rate. In that case, the black market premium is akin to an import tariff, since the premium measures the excess cost of importables relative to exportables. ${ }^{14}$ The black market premium then attracts resources into import-competing sectors, since the domestic price of such goods includes the black market premium, and out of nontradables and exportables.

Consider the effect of a demand expansion starting from an initial balance of payments equilibrium under this new exchange rate regime. Once again the price of nontradables will tend to rise, while downward pressure will be put on the exchange rate. However, now the central bank responds by rationing foreign exchange, with the result that the black market premium on foreign currencies rises. This secondary effect punishes exporters at the expense of importers. Overall, the demand expansion induces a real currency appreciation measured at the official exchange rate, a rise in the black market premium on foreign exchange, a rise in nontradables production, and a sharp drop in exportables production. The effect on import-competing goods is ambiguous.

The anti-export bias of a black market premium is one of the two principal income distributional effects of a split exchange rate. The second effect involves the way in which the central bank rations the foreign exchange that it in fact sells at the official exchange rate. Recipients of scarce foreign exchange at preferred prices clearly receive a windfall, akin to the earnings that privileged importers earn under trade quotas. In most of Latin America, scarce foreign exchange is allocated to protected industrial firms that use the foreign exchange to purchase primary inputs from abroad. The value of the rents attached to these inexpensive purchases can be several percent of GNP, and are clearly a major political obstacle to any attempt to devalue and unify the exchange rate.

Data on exchange rate management shown in table 6 suggest that Latin American currencies, measured at official parities, became over-

14. Exportables will sometimes be smuggled in response to the incentive created by the black market premium on foreign exchange. Since smuggling is likely to involve both private costs (for example, bribes) and social costs (for example, roundabout transport), even the smuggling exporter will not receive, on net, the black market exchange rate for his sales. 
Table 6. Exchange Rate Management, Selected Periods ${ }^{a}$

Percent

\begin{tabular}{lccc}
\hline & $\begin{array}{c}\text { Real } \\
\text { appreciation, } \\
\text { 1979-81 over } \\
1976-78\end{array}$ & \multicolumn{2}{c}{$\begin{array}{c}\text { Black market premium } \\
\text { on currency }\end{array}$} \\
\cline { 3 - 4 } Country & & $1977-81$ & $1982-83$ \\
\hline Latin America & 36.9 & 10.7 & 36.0 \\
Argentina & -20.5 & 16.9 & 51.8 \\
Brazil & 7.5 & 6.1 & 29.6 \\
Chile & 13.3 & 2.4 & 32.7 \\
Mexico & -7.2 & 5.0 & 1.0 \\
Peru & 7.0 & 0.2 & $\ldots$ \\
Venezuela & 2.9 & 9.4 & 40.4 \\
$\quad$ Weighted average & 10.4 & 0.9 & 6.9 \\
Colombia & & & \\
East Asia & -29.7 & 2.3 & 9.1 \\
Indonesia & 3.8 & 9.0 & 10.0 \\
Korea & -4.6 & 0.1 & 0.5 \\
Malaysia & 1.0 & -0.7 & 0.5 \\
Thailand & -10.5 & 3.7 & 6.9 \\
$\quad$ Weighted average & 6.7 & 6.8 & 16.2 \\
Philippines & & & \\
\hline
\end{tabular}

Sources: Official exchange rates and price data are from International Financial Statistics, series ae and 64; black market rates (or parallel market rates) are from 1984 World Currency Yearbook (International Currency Analysis, Inc., 1984).

a. The real exchange rate is calculated for each year as $E P * / P$, where $E$ is the official exchange rate in units of domestic currency per dollar, $P^{*}$ is the U.S. consumer price index, and $P$ is the domestic price index. All variables are annual averages. The black market premium is computed for the months of March, June, September, and December, using official rates and the black market rates. Annual average premiums are then computed.

b. Not comparable for Venezuela, since in the split exchange rate system operating since 1983, nontraditional exports are sold at the parallel market rate, and hence are subsidized. However, private sector nontraditional exports represent less than 3 percent of total exports.

valued (with the notable exception of Brazil's and Peru's) in the late 1970s and early 1980s, and that Latin American countries have frequently allowed very large premiums to develop in the black market in the face of downward pressure on the official exchange rate. Column 1 of the table measures the real appreciation of selected currencies during 197981 compared with a base period of 1976-78. The largest appreciation recorded is that of Argentina (36.9 percent), followed by Mexico, Chile, and Venezuela. Measured by relative consumer price indexes (CPIs), Brazil in fact had a hefty real depreciation, Peru a somewhat smaller one. In Asia, all countries except Indonesia maintained the real exchange rate within 10 percent of the 1976-78 values. Moreover, the Latin American countries have allowed large black market premiums to 
develop in recent years, particularly after the onset of the debt crisis, while the Asian countries have generally kept small the discrepancies between the official and black market rates.

There are several reasons for the real appreciation throughout Latin America, but I suggest later that common political developments leading to such appreciations, and to their persistence for several years, are at work. In terms of proximate causes, it is necessary to distinguish between the two Southern Cone countries included in the table, Argentina and Chile, and the two major oil exporters, Mexico and Venezuela. The story in the Southern Cone is by now well known: Argentina, Chile, and Uruguay all embarked upon a path of disinflation, with a strong currency policy helping to reduce inflationary expectations. ${ }^{15}$ In Mexico, and in Venezuela to a lesser extent, the real appreciation resulted from oilinduced increases in domestic spending that crowded out tradable goods sectors, à la the "Dutch disease."

It is worth noting that the Asian policy of maintaining the real exchange rate has been extended to encompass a basket of currencies, rather than focusing exclusively on the bilateral rate with the U.S. dollar. During the years when the Bretton Woods system was in effect, and for several years after its demise, the Asian economies maintained fixed rates against the dollar. However, by 1978, all of the countries in the region were worried about the large fluctuation of the dollar vis-à-vis other industrial country currencies. In rapid succession, Thailand, Korea, Indonesia, and Malaysia all switched from a dollar peg to an exchange rate basket. In Latin America, on the other hand, no country adopted a basket. All continued to peg to the U.S. dollar, either at a fixed parity, as in Mexico, Venezuela, and Chile after 1979, or in a crawling peg, as in Argentina, Brazil, Colombia, and Peru. All suffered, to some extent inadvertently, when the dollar appreciated sharply after 1980.

THE ROLE OF GOVERNMENT FISCAL POLICIES

Overall domestic fiscal policies are alleged to have contributed to the Latin American debt crisis in at least two ways. First, some supply-

15. For an excellent retrospective, complete with extensive references, see Vittorio Corbo, Jaime de Melo, and James Tybout, "What Went Wrong with the Recent Reforms in the Southern Cone," Discussion Paper (World Bank, July 1985), forthcoming in Economic Development and Cultural Change. 
siders argue that successful performance has resulted from low marginal tax rates; failure, from high rates. For several years under the Reagan administration, U.S. policy at the International Monetary Fund has been to push adjustment programs toward expenditure cutting rather than tax increases as the means of reducing budget deficits in countries undertaking stabilization programs. In Congress, Jack Kemp and others have argued for tying U.S. foreign aid to tax cuts in recipient countries. A second, and more conventional, allegation is that the Latin American governments have run larger budget deficits and, on balance, more expansionary fiscal policies than have their Asian counterparts. The results of such fiscal expansion supposedly include both higher inflation and a diversion of resources into nontradables.

It is not easy to collect evidence on the marginal tax rates of a large sample of countries. One recent and widely cited study at the World Bank, by Keith Marsden, has therefore looked at average tax revenues in GDP, to see if there is a negative correlation between average tax rates and economic performance across countries. Marsden concluded that such a negative effect was evident. ${ }^{16}$ The evidence on average tax rates in Latin America, however, casts strong doubts on the simple proposition that these countries have overtaxed their private sectors. To the contrary, many Latin American countries, particularly Argentina and Mexico, appear to have a difficult time raising sufficient government revenues through normal tax collection, and so have resorted to inflationary money printing to finance state expenditure. The first column of table 7 records the level of taxes as a proportion of GDP for the two regions in 1982, and the second, the annual collection of seignorage "taxes" due to money creation, on average, for 1975-83. With respect to central government revenues, there is strong diversity within the two regions and no clear pattern between regions. However, with respect to the inflation tax, shown in the second column, only the Latin American economies have made significant use of this form of revenue collection. In Asia, average annual seignorage is everywhere below 2.0 percent of GDP.

Just as tax-GDP ratios are widely variable within the regions, with no strong pattern across regions, so too with central government expendi-

16. Keith Marsden, "Links between Taxes and Economic Growth: Some Empirical Evidence," Working Paper 605 (World Bank, August 1983). 
Table 7. Indicators of Fiscal Position ${ }^{a}$

\begin{tabular}{lccc}
\hline \multicolumn{1}{c}{ Country } & $\begin{array}{c}\text { Revenues as } \\
\text { percentage of } \\
\text { GDP, 1982 }\end{array}$ & $\begin{array}{c}\text { Seignorage } \\
\text { collection as } \\
\text { percentage of } \\
\text { GDP, } 1975-83\end{array}$ & $\begin{array}{c}\text { Government } \\
\text { expenditures as } \\
\text { percentage of } \\
\text { GNP, 1982 }\end{array}$ \\
\hline Latin America & & & \\
Argentina & 16.5 & 10.8 & 21.6 \\
Brazil & 26.1 & 2.2 & 21.8 \\
Chile & 32.0 & 2.5 & 37.6 \\
Mexico & 17.0 & 5.5 & 31.7 \\
Peru & 16.8 & 5.7 & 18.0 \\
Venezuela & 29.3 & 1.8 & 29.6 \\
$\quad$ Weighted average & 22.2 & 4.6 & 25.8 \\
Colombia & 11.7 & 2.7 & 14.0 \\
East Asia & & & \\
Indonesia & 22.2 & 1.3 & 23.5 \\
Korea & 19.1 & 1.5 & 19.5 \\
Malaysia & 29.2 & 1.6 & 41.0 \\
Thailand & 13.9 & 1.0 & 19.9 \\
$\quad$ Weighted average & 20.6 & 1.4 & 23.7 \\
Philippines & 11.2 & 1.1 & 12.2 \\
\hline
\end{tabular}

Sources: Fiscal data are from World Development Report 1985. Reserve money (series 14) and GDP are from International Financial Statistics.

a. Revenues and expenditures are for the central government. Seignorage as a percentage of GDP for year $t$ is calculated as $\left(M_{t}-M_{t-1}\right) / G$, where $M_{t}$ is end-of-year reserve money and GDP is nominal GDP for the year.

tures as a percentage of GDP. It is not the case, as evidenced in the third column of the table, that public sector spending is notably less in Asia than in Latin America. Economic success is not a simple outturn of a small public sector.

A more likely factor in Latin American problems is the size of budget deficits, not the size of government per se. However, it is remarkably difficult to obtain cross-country budget-deficit data that are both consistent and reliable. Several formidable problems must be overcome in making deficit comparisons. Published data (for example, in the Government Financial Statistics of the International Monetary Fund) rely almost exclusively on the central government net of state enterprises. Yet it is widely appreciated that state enterprises have accounted for a significant portion of consolidated government deficits in recent years. Moreover, meaningful deficit comparisons should correct for accounting biases introduced by inflation. For example, a switch from unindexed government liabilities to indexed government liabilities would greatly 
reduce measured deficits under the accounting conventions of most countries. Without comprehensive data on the structure of internal indebtedness of a government, it is not possible to make an adequate inflation adjustment. Another problem is that different definitions of taxation and borrowing can heavily skew the measured deficit. For example, in Malaysia, enormous deficits are financed by a forced savings scheme that most countries would regard as a form of social security taxation. In Malaysia it is seen as borrowing, not taxation.

Nuriel Roubini has recently overcome at least one of these problems by constructing deficits for the consolidated public sectors, including both central governments and state enterprises, for nineteen developing countries, including many in Latin America and Asia. His results are reproduced in table 8 . In his sample, there is a clear pattern of higher deficits among the rescheduling countries in the years leading up to the reschedulings. Given the large weights of Asia and Latin America in the sample, there is a suggestion that the Latin American deficits have in fact been larger. That finding would also be consistent with the higher inflation and seignorage taxation already observed.

\section{THE ROLE OF GOVERNMENT IN THE PRODUCTION PROCESS}

Many commentators have argued that it is not taxes or deficits per se, but rather the degree of government intervention, that explains the difference in performance in Asia and Latin America. Not surprisingly, Milton Friedman has strongly endorsed this view: "Every successful country [Taiwan, South Korea, Singapore, Hong Kong, Japan] has relied primarily on private enterprise and free markets to achieve economic development. Every country in trouble has relied primarily on government to guide and direct its economic development." ${ }^{17}$ However strong the temptation to regard the Asian performance as a victory for free enterprise, the historical record belies such a simple interpretation. Ching-yuan Lin argues persuasively that, with the possible exception of Hong Kong, the Asian experience is not one of an unfettered market economy, but rather one of enlightened policy activism of national governments: "The institutional framework of Taiwan and South Korea

17. Milton Friedman, “' 'No' to More Money for the IMF,', Newsweek (November 14, 1983), p. 96. 
Table 8. Fiscal Deficits Relative to GDP, $1977-\mathbf{8 3}^{\mathrm{a}}$

Percent

\begin{tabular}{cccc}
\hline \multicolumn{4}{c}{ Nineteen market borrower countries } \\
\cline { 2 - 4 } Year & $\begin{array}{c}\text { With recent } \\
\text { debt servicing } \\
\text { problems }\end{array}$ & $\begin{array}{c}\text { Without debt } \\
\text { servicing } \\
\text { problems }\end{array}$ & $\begin{array}{c}\text { All nineteen } \\
\text { countries }\end{array}$ \\
\hline \multicolumn{4}{c}{ Central } \\
1977 & -2.8 & -1.9 & -2.5 \\
1978 & -2.8 & -1.7 & -2.4 \\
1979 & -1.2 & -2.0 & -1.5 \\
1980 & -2.2 & -1.8 & -2.1 \\
1981 & -4.4 & -4.6 & -4.5 \\
1982 & -5.7 & -5.3 & -5.5 \\
1983 & -6.1 & -4.0 & -5.2 \\
& - Nonfinancial public sector & -3.9 & -4.0 \\
1977 & -4.1 & -3.4 & -5.1 \\
1978 & -6.1 & -3.2 & -4.7 \\
1979 & -5.7 & -3.4 & -4.7 \\
1980 & -5.4 & -5.8 & -9.5 \\
1981 & -11.5 & -6.9 & -12.1 \\
1982 & -15.2 & -5.8 & -9.8 \\
1983 & -12.4 & balances & palances \\
\hline
\end{tabular}

Source: Nuriel Roubini, "The Origins and Causes of External Debt Servicing Difficulties," S-I paper (IMF, August 1985), table 12.

a. Averages of country data weighted by U.S. dollar value of GDP in each year.

can hardly be characterized as laissez-faire. . . . Through a timely and active promotion of exports and industrial efficiency, the authorities in Taiwan and South Korea nevertheless helped to create a sustainable growth pattern based on their dynamic comparative advantages." 18 Colin Bradford has recently reached the same conclusion in a very useful, well-referenced study. ${ }^{19}$

Recent empirical work by R.P. Short makes it possible to assess the relative roles of state enterprise in the two regions. ${ }^{20}$ According to the data reproduced in table 9 , there is no strong evidence that state

18. See Ching-yuan Lin, "Latin America and East Asia," chapter 2.

19. See Colin Bradford, "East Asian Development Strategies as Models for Development," in John P. Lewis, ed., Development Strategies: A New Synthesis (New Brunswick: Transaction Books, forthcoming).

20. See R.P. Short, "The Role of Public Enterprise: An International Statistical Comparison," in Robert H. Floyd and others, Public Enterprise in Mixed Economies: Some Macroeconomic Aspects (IMF, 1984). 
Table 9. The Macroeconomic Role of Public Enterprise, Selected Years

Percent

\begin{tabular}{llccc}
\hline Country & Year & $\begin{array}{c}\text { Share of } \\
\text { GDP }\end{array}$ & $\begin{array}{c}\text { Share of } \\
\text { fixed } \\
\text { investment }\end{array}$ & $\begin{array}{c}\text { Deficit as } \\
\text { percentage } \\
\text { of GDP }\end{array}$ \\
\hline $\begin{array}{l}\text { Latin America } \\
\text { Argentina }\end{array}$ & $1978-80$ & 4.6 & & \\
Brazil & 1980 & n.a. & 22.8 & n.a. \\
Chile & $1978-80$ & 13.0 & 12.9 & 1.7 \\
Mexico & 1978 & n.a. & 29.4 & 0.4 \\
Peru & $1978-79$ & n.a. & 14.8 & 3.7 \\
Venezuela & $1978-80$ & 27.5 & 36.3 & 1.7 \\
Colombia & $1978-80$ & n.a. & 8.9 & 5.1 \\
East Asia & & & & n.a. \\
Korea & $1974-77$ & 6.4 & 25.1 & \\
Taiwan & $1978-80$ & 13.5 & 32.4 & $5.2^{\mathrm{a}}$ \\
Thailand & $1978-79$ & n.a. & 12.8 & 5.5 \\
Philippines & 1978 & n.a. & 10.9 & 2.0 \\
\hline
\end{tabular}

Source: All data are from R.P. Short, "The Role of Public Enterprise: An International Statistical Comparison," in Robert H. Floyd and others, Public Enterprise in Mixed Economies: Some Macroeconomic Aspects (IMF, 1984), pp. 110-96. Indonesia data were not available.

n.a. Not available.

a. $1978-80$.

enterprise plays a more important role in Latin America than in Asia. Both Korea and Taiwan allocate an enormous share of national fixed capital formation through state enterprise, indeed a higher share than in any of the Latin American countries except Mexico and Venezuela, where government investment in the oil sector is heavy. Similarly, the share of GDP originating in state enterprises is apparently greater in Korea and Taiwan than in Argentina.

To the extent that differences in government intervention have played a large role in explaining economic performance, the differences are apparently in the quality of policy rather than the sheer weight of government in the economy.

\section{A SUMMARY}

Of all the causes of poor Latin American economic performance considered so far, the most significant seem to be trade and exchange rate policies. Put simply, the Latin debt became burdensome both because of its structure (short maturities, variable interest rate) and 
because of insufficient exports available to service it. After a decade of rapid foreign borrowing, too many of Latin America's resources were in the nonexporting sector, or abroad. When a financial squeeze in the early 1980s caused banks to draw in their loans, the only way that the Latin countries could maintain debt servicing was through a recession and a sharp reduction in imports combined with debt reschedulings.

Capital flight, high inflation, and, perhaps, larger public deficits have also contributed to Latin America's poor performance, in part by exacerbating the bias against exportables. There is little evidence that excessive current account deficits or excessively large public sectors or state enterprises played a leading role.

\section{The Political Economy of Export-Led Growth}

Whatever the abstract merits of an export-promotion strategy relative to an import-substitution strategy for an economy with little foreign debt, the Latin American economies will need a dramatic increase in exports if they are both to grow and to service their external debts. A continuation of policies opposed to export growth will make debt servicing impossible or will condemn these countries to many further years of stagnation, or both. In the past thirty years, most of the Latin American economies have accomplished about as much as possible in the way of import substitution, with current imports limited to primary inputs and drastically reduced levels of capital goods. As Diaz-Alejandro has noted, the trade surpluses needed to generate foreign exchange to service the external debt have so far been achieved through drastic reductions in imports, in turn the product of deep recessions in the Latin American economies. ${ }^{21}$ Economic growth will require increases in imports of capital goods, which must be financed through increased export sales.

The debate over debt repayments in Latin America is being conducted not only between debtor countries and international creditors, but also between factions in each country that would benefit or lose from a shift to export promotion. Workers whose real wages would be reduced by an export-promoting devaluation of the currency, and state enterprises

21. Diaz-Alejandro, "Latin American Debt." 
that enjoy cheap foreign inputs at the overvalued official exchange rate, argue that debt repayments represent an unconscionable levy on the country by foreigners and must not be paid. Agricultural interests and exporters of nontraditional exports argue instead that the economy should be liberalized and the currency devalued. As the final section of the paper shows, this debate has paralyzed economic policy in most of the Latin American countries since 1982.

A growing literature in international trade theory has developed a political economy of protectionism and rent-seeking that uses general equilibrium models to assess gains and losses to different interest groups as a result of alternative public policies. ${ }^{22}$ The assumption is that interest groups lobby on behalf of self-serving policy actions, with actual policy outcomes depending on the balance of power of the different groups in the political system. This kind of modeling has helped to explain, for example, the nature of the tariff structure in the United States and Canada in terms of the size and cohesion of different interest groups and voting blocs. Such work for the developing countries is inherently more difficult, since political processes in these countries are typically less democratic and less transparent.

So far, the framework of political lobbying for distributional gains has been applied mostly to trade policies, but it can also be applied to the issue of exchange rate management. Under which circumstances will a government choose to maintain an overvalued currency or to allow a sharp premium in the black market rate? Under which circumstances will a government attempt to fight inflation, as in the United States, through a sharp real appreciation of the currency, as opposed to a deeper recession with a stable real exchange rate? No doubt, the present political weakness of the U.S. middle west, the "rust belt" and the "farm belt," has enabled the strong dollar strategy to persist; in more open economies, the political pressures against such a strategy might have proved overwhelming.

Without attempting a comprehensive discussion of this issue, I think that certain key elements in political and economic organization can help to account for the differing exchange and trade regimes in Latin America and Asia.

22. See, for example, chapters 7-13 of Jagdish N. Bhagwati, ed., Import Competition and Response (University of Chicago Press, 1982). 
The income distributional effects of alternative trade regimes are naturally very complex. Specific effects depend on the nature of trade controls (whether tariffs or quotas), the level at which controls are applied (whether on final consumption goods or on primary and intermediate products), the structure of supply (whether the country exports agricultural or manufacturing goods), the distribution of quota rights or tariff revenues, and so forth. But in almost every case, trade restrictions tend to shift income from the agricultural and mineral producing sectors toward the industrial and service sectors. Since the agricultural work force in most middle-income developing countries is typically between 30 percent and 50 percent of the total, and since agriculture and mining account for a quarter or more of domestic GDP in most cases, the political and economic effects of this particular income redistribution can be profound.

These distributional effects provide some clues as to why the Latin American countries have chosen to rely on an overvalued currency, a large service sector, and a small export sector, while the Asian economies have lived with the reverse. I believe that long-term differences in the balance of power between urban and rural interests help to account for much of the discrepancy. To a first approximation, the Latin American governments-whether civilian or military, right-wing or left-wing-find their most important constituencies among urban workers and capitalists. For decades, the agricultural sector has been relatively weak, though certainly not powerless, almost everywhere in Latin America, with peasants only loosely organized and, with some exceptions, largescale agricultural interests unable to hold decisive sway. Moreover, political unrest is most dangerous in the cities, so that urban interests must be bought off first in difficult periods. Interestingly, the opposite seems to be true in most of East Asia. Governments there, whether Japanese colonial rulers before World War II or nationalist governments, have felt the pressing need to win support of, or at least to appease, the rural sector.

THEORETICAL EVIDENCE

The computable general equilibrium (CGE) models developed by Jaime de Melo, Sherman Robinson, Kemal Dervis, and others provide the best evidence of intersectoral resource shifts and income as a result 
of trade and exchange rate policies. In a CGE model for Colombia, for example, de Melo and Robinson compare the income distributional aspects of an inward-looking strategy, a tariff on manufacturing imports, with those of an outward-looking strategy, an export subsidy on manufacturing and noncoffee agriculture. ${ }^{23}$ The authors compute the factor shares of different social groups across the two regimes, with the following result (aggregated over their six-group disaggregation):

\section{Group share of income}

Rural (capitalists plus labor)

Urban (capitalists plus labor, industry, and services)

\begin{tabular}{cc}
\multicolumn{2}{c}{ Policy } \\
\hline Inward & Outward \\
36.2 & 38.1 \\
63.8 & 61.9
\end{tabular}

Tariffs raise the price of home goods, reducing the agricultural sector's terms of trade, and thereby reducing the share of income originating in the export sector. The magnitudes of the changes involved are naturally country-specific (and model-specific) and depend on the degree to which the policies are pursued, but the direction of effect is probably quite robust.

The same logic applies to exchange rate policy in response to an external disturbance. Suppose that a developing country faces a rise in the world price of imports relative to the world price of its exportables, as occurred for most of the developing countries in the early 1980s. Consider three possible policy responses to that disturbance. In the first, the country maintains external balance by devaluing the exchange rate. In the second, it maintains current account balance by maintaining the official parity, but allowing a large discount to develop on the home currency in a parallel or black market. In the third, it maintains the parity and preserves the unified exchange rate. The real exchange rate is kept constant by a fiscal expansion financed by foreign borrowing or by a drawdown of official foreign exchange reserves. These alternative policies will show important differences in their distributional effect, with the rural-urban distinction once again playing an important role.

In the first case, the terms-of-trade loss reduces national income and

23. See Jaime de Melo and Sherman Robinson, "The Impact of Trade Policies on Income Distribution in a Planning Model for Colombia," Journal of Policy Modeling, vol. 2 (January 1980), pp. 81-100. 
leads to a drop in the demand for nontraded goods. The price on nontradables declines relative to the price of tradables, and resources are induced to flow into the tradables sectors. This increase in tradables production provides the resources necessary to balance the current account after the decline in the external terms of trade. In the second case, only the black market exchange rate depreciates. Once again, nontradables demand falls, but now only the price of import-competing goods rises significantly (the price of exportables rises relative to nontradables and falls relative to importables). There is a rise in importables production, a fall in nontradables production, and an ambiguous effect on exportables production. The resources needed to maintain current account balance come mainly from further import substitution rather than from export promotion. In the third case, the price of nontradables does not fall relative to tradables. Overall national absorption stays higher than it does in the first two cases, because the government undertakes a foreign-financed fiscal expansion. Of course, domestic absorption ultimately will have to decline in order to service the accumulated foreign debt, but that eventuality can be postponed until well into the future.

The income distributional aspects of the three cases are of course complex. For example, in the second case, with foreign exchange rationing and a black market premium on foreign exchange, much of the income distributional effect will depend on whom the central bank designates as recipients of official foreign exchange sales. In another paper, de Melo and Robinson have analyzed the income distributional effects of the first two cases, with results that can also be used to infer the implications of the third. ${ }^{24}$ They consider an across-the-board increase in import prices and an across-the-board downward shift in export demands. In the case of foreign exchange rationing, they assume that capitalists in the industrial and service sectors are allocated the scarce foreign exchange in order to make purchases of intermediate inputs, with other groups required to purchase foreign exchange on the black market. They then consider the distributional effects of devaluation versus rationing on seven population groups, with the results as shown in table 10. The table records the change, in percentage points, in each

24. See Jaime de Melo and Sherman Robinson, "Trade Adjustment Policies and Income Distribution in Three Archetype Developing Economies," Journal of Development Economics, vol. 10 (February 1982), pp. 67-92. 
Table 10. Effects of Terms-of-Trade Shocks on Income Distribution, Alternative Exchange Rate Policies

Percent

\begin{tabular}{lccc}
\hline & \multicolumn{3}{c}{ Changes in share of income $^{\mathrm{a}}$} \\
\cline { 2 - 4 } Income group & $\begin{array}{c}\text { Devaluation } \\
(1)\end{array}$ & $\begin{array}{c}\text { Rationing } \\
(2)\end{array}$ & $\begin{array}{c}\text { Difference } \\
(1)-(2)\end{array}$ \\
\hline Farmers & 1.3 & -2.6 & 3.9 \\
Marginal labor & 0.4 & -0.1 & 0.5 \\
Organized labor & 0.2 & 0.0 & 0.2 \\
Service labor & -0.4 & 1.4 & -1.8 \\
Agricultural capital & -0.6 & -3.2 & 2.6 \\
Industrial capital & -0.2 & 3.4 & -3.6 \\
Service capital & -0.7 & 1.1 & -1.8 \\
Total & 0.0 & 0.0 & 0.0 \\
\hline
\end{tabular}

Source: Jaime de Melo and Sherman Robinson, "Trade Adjustment Policies and Income Distribution in Three Archetype Developing Economies," Journal of Development Economics, vol. 10 (February 1982), p. 82.

a. From model base run.

group's share of total national income. Overall changes, summing over the various population groups, necessarily total zero.

The third column shows the differences in distribution arising from a formal devaluation on the one hand and a split rate, with a constant official rate and a black market devaluation, on the other. The real battle is between agricultural labor and capital on one side and the urban capitalists and service labor on the other. The agricultural interests clearly benefit enormously from the devaluation. The alternative, the split rate, results both in low food prices and in the capitalists receiving the favorable official foreign exchange. Both punish the agricultural sector and benefit the urban sector.

The third alternative policy, not explicitly considered by de Melo and Robinson, would maintain the real exchange rate through a foreignfinanced fiscal expansion and would have more neutral effects on income distribution. Since the foreign borrowing is necessarily temporary, it can be seen as a mechanism for forestalling the choice over income distribution that is thrown up by the foreign shock. This third alternative does not serve the short-term agricultural interests as well as would a devaluation, nor the urban interests as well as would the split rate. Eventually, however, the foreign capital inflow will cease, and the distributional fight will be more severe than in either of the other two cases, since on top of the problem of a terms-of-trade decline will be the 
problem of servicing an accumulated stock of foreign debt. The choice of whether to service that debt through explicit devaluation or rationed foreign exchange will be essentially the same as the choice offered by the original terms-of-trade shock.

These distributional effects of trade and exchange rate policies have long been noted by observers of Latin America, including Alexandre Kafka and Albert Hirschman. ${ }^{25}$ Consider, for example, Hirschman's observations on exchange rate policy:

In effect, maintaining an overvalued exchange rate meant that the exporters of traditional primary products would receive a smaller real income than with an equilibrium or undervalued exchange rate. At the same time, the overvalued exchange rate permitted the acquisition at favorable prices (in domestic currency) of those imports that were let in by the control authorities. And since machinery and essential industrial materials enjoyed preferential status, the overvalued exchange rate acted as a mechanism to transfer income from the traditional export sector to the new industries. ${ }^{26}$

Interestingly, Hirschman goes on to ask why the same distributional results could not have been achieved in a way that did not punish manufacturing or nontraditional exports:

For example, why not tax the export sector, subsidize the new industries and do away with the overvalued exchange rate so that industrial exports are encouraged? To ask this question is to answer it: in most Latin American countries such a course would have been politically impossible. The power of the groups tied to the primary export sector would hardly have permitted so direct an assault. ${ }^{27}$

Hirschman argues that the overvaluations were successful in transferring income not only because they were indirect, but also because their effects were unrecognized by key sectors, even-though this is hard to believe-the agricultural sector.

The rural-urban distinction is but one element in a very complicated picture. Ideology, foreign policy, and even national security considerations have also contributed to differences in policy, and, indeed, many distinctions across countries within Latin America and Asia make any overarching generalizations treacherous. Several qualifications are therefore in order. First, there is no historical inevitability to the relative

25. Albert O. Hirschman, A Bias for Hope (Yale University Press, 1971), and Alexandre Kafka, "The Theoretical Interpretation of Latin American Economic Development," in Howard S. Ellis, ed., Economic Development for Latin America (St. Martin's Press, 1961).

26. Hirschman, A Bias for Hope, p. 117.

27. Ibid., p. 118. 
influence of agricultural versus urban interests in the two regions. It is well known that up until the Great Depression, large rural landholders in Latin America provided the dominant political power within the ruling oligarchies. And, indeed, until the Great Depression, trade policies throughout Latin America were stringently liberal, in line with the class interests of the ruling oligarchs. The shift to import substitution and vigorous protection of domestic industries dates from the decline of the relative power of the agricultural sector during the Great Depression. Similarly, in Asia, countries such as Korea and Indonesia pursued an import-substitution policy complete with Latin American-style inflation rates during the 1950s. It is not that rural strength in Asia made an exportpromoting strategy inevitable; rather, rural strength helped to tip the balance in that direction in the 1960s, when the East Asian countries began their export drives.

Second, countries within a region differ substantially in their urbanrural balance. Large agricultural interests, particularly in coffee, have remained powerful in Colombia, for example, and were a substantial political force behind Colombia's liberalization in the mid-1960s. Third, intellectual and ideological elements have played a significant role, along with strict economic interests, in defining the trade and exchange rate policies in Latin America and Asia. Dependency theory and opposition to U.S. involvement in local economies have contributed to the strength of protectionist sentiment throughout Latin America. The influence on Latin governments of the Prebisch hypothesis that agriculture and primary products were a losing long-term bet for economic growth also contributed to the formulation of the import-substitution policy.

\section{EMPIRICAL EVIDENCE ON URBAN VERSUS RURAL POLITICS}

Some very rough indicators suggest why the hypothesis of greater rural power in Asia is at least plausible. As shown in table 11, column 1, the population in Asia remains largely rural, while the Latin American population is overwhelmingly urban. This difference remains very strong even after controlling statistically for per capita incomes across countries (not shown). Korea, now highly urbanized, is the single Asian exception, but it is not in contradiction to the thesis that rural political power is a force for export-oriented trade policies. Korea's decisive devaluations and export-promotion policies were instituted during the five years after 
Table 11. Indicators of Urban versus Rural Power

\begin{tabular}{|c|c|c|c|c|c|}
\hline \multirow[b]{2}{*}{ Country } & \multirow{2}{*}{$\begin{array}{c}\text { Degree of } \\
\text { urbanization } \\
1980 \\
\text { (percent) }\end{array}$} & \multirow{2}{*}{$\begin{array}{c}\text { Degree of } \\
\text { unionization } \\
\text { (percent) }\end{array}$} & \multicolumn{3}{|c|}{$\begin{array}{l}\text { Net exports of agriculture } \\
\text { (percentage of } G D P)\end{array}$} \\
\hline & & & 1962 & 1980 & Change \\
\hline \multicolumn{6}{|l|}{ Latin America } \\
\hline Argentina & 82 & 16.6 & 11.3 & 3.0 & -8.3 \\
\hline Brazil & 68 & 36.6 & 4.4 & 3.0 & -1.4 \\
\hline Chile & 80 & 8.0 & -0.5 & 0.9 & 1.4 \\
\hline Mexico & 67 & 8.6 & 2.7 & -0.7 & -3.4 \\
\hline Peru & 67 & 3.4 & 8.3 & 0.0 & -8.3 \\
\hline Venezuela & 83 & 24.5 & -0.8 & -3.4 & -2.6 \\
\hline Weighted average & 72 & 22.2 & 4.5 & 1.2 & -3.3 \\
\hline Colombia & 70 & n.a. & 6.3 & 7.2 & 0.9 \\
\hline \multicolumn{6}{|l|}{ East Asia } \\
\hline Indonesia & 20 & 3.4 & n.a. & 4.3 & n.a. \\
\hline Korea & 55 & 4.3 & -3.8 & -4.2 & -0.4 \\
\hline Malaysia & 29 & 7.2 & 10.3 & 18.6 & 8.3 \\
\hline Thailand & 14 & 0.4 & 11.3 & 8.6 & -2.7 \\
\hline Weighted average & 31.5 & 3.7 & 3.1 & $3.5^{\mathrm{a}}$ & -0.4 \\
\hline Philippines & 36 & 16.3 & 8.0 & 5.1 & -2.9 \\
\hline
\end{tabular}

Sources: Urbanization is measured as the proportion of the population living in urban areas, from World Development Report 1982. Unionization is measured as number of union members relative to working age population (ages 15-64). Union membership is from U.S. Bureau of Labor Statistics, International Labor Affairs Office, unpublished data. All data are for 1983 or 1984, except for Mexico (1982) and Venezuela (1979). Net agricultural exports are from various issues of FAO Trade Yearbook (United Nations, Rome, 1983). The trade category considered is agricultural products, total, net of fertilizers and farm machinery.

n.a. Not available.

a. Excluding Indonesia, for purposes of comparison with 1962.

1960, when Korean urban dwellers composed only 28 percent of the nation's total population. The second column of the table shows the extent of labor unionization in the two regions. Unions are, of course, mostly an urban phenomenon. Not surprisingly, the Latin American countries are far more unionized than are their Asian counterparts. Since urban workers are a major interest group in favor of overvalued exchange rates, this difference in labor market organization certainly plays an important role in the political calculus.

Interestingly, even though the rural poor represent the lowest economic class in Latin America, reformist regimes in the hemisphere have typically focused mostly on the urban poor. According to John Sheehan, who has analyzed the political choices made by the left-wing Velasco government in Peru in the 1970s, "Urban labor usually identifies "poverty' with itself. The peasants and landless rural labor are out of sight. . . . The Velasco regime seemed to start out with the rural poor in mind, but 
when the squeeze became intense, these same poor dropped out of the policy picture." 28

The last three columns of table 11 show, if not the relative power of agriculture, at least the difference in outcomes for agriculture in the two regions. These columns record the net exports of agricultural commodities as a share of GDP in 1962 and 1980, as well as the change in the share over those years. There were large declines in the net export ratio in Argentina, Brazil, Mexico, Peru, and Venezuela. Only Chile shows an increase. In Asia, Korean net imports of agriculture maintained a nearly constant share of GDP, while the agricultural net exports of Malaysia grew sharply. In Thailand the net export ratio declined significantly, but from a very high level. In Asia, the net export share of agricultural goods relative to GDP rose by 0.4 percentage point between 1962 and 1980, while it declined by more than 3 percentage points in Latin America.

To tie down the relationship of agricultural political power and export promotion would require a detailed country-by-country study, though an initial examination of the historical record in several countries lends credence to the hypothesis. In Argentina, for example, it is clear that the urban-based political power of Peron, combined with the political weakness of agriculture due to low world prices in the Great Depression, contributed to the decisive shift away from export promotion. According to Eugenio Maffucci and Lucio Reca:

The distrust of agriculture and the search for a more promising alternativewhich turned out to be industrialisation via import substitution-was reflected in a set of policies covering the whole spectrum, from heavy taxes in the form of low product prices [in agriculture] enforced through state monopoly in the marketing of grain, to the gradual abandonment of research and development in plant breeding except for wheat. ${ }^{29}$

Up to the Great Depression, the agricultural interests had succeeded in maintaining free trade and a competitive exchange rate. Henry Wallich has recently noted a fascinating example of this link of agricultural interests with the currency, at the end of the nineteenth century. The

28. John Sheehan, "The Economics of the Peruvian Experiment in Comparative Perspective,"' in Cynthia McClintock and Abraham F. Lowenthal, eds., The Peruvian Experiment Reconsidered (Princeton University Press, 1983), pp. 387-414.

29. See Eugenio A. Maffucci and Lucio G. Reca, "Agricultural Exports and Economic Development: The Case of Argentina," in Nural Islam, Agricultural Policy in Developing Countries (Halsted, 1974), p. 227. 
policy debate in Argentina in the 1890s was over the return to gold parity, which would have required an appreciation of the currency. Wallich notes:

But the issue of returning to parity was less a matter of economic theory than economic interest. Appreciation of the peso was hard on exporters and the agricultural interests that supplied the exports. These were the principal economic interests and the strongest political factor, consisting importantly of large landowners but also small farmers and rural workers. They opposed a return to par, though they were amenable to stabilization at some lower level..$^{30}$

And that is what occurred.

In more recent times, that group has not won its battles over trade policy or the exchange rate. Data developed by Diaz-Alejandro show how effective Peron's trade and exchange rate policies were in turning the terms of trade against the rural sector. The ratio of the wholesale prices of rural to nonrural goods dropped from a base of 100 during $1935-$ 39 to 68 during $1953-55,78$ during 1956-58, 85 during 1959-61, 93 during 1962-64, 78 during 1965-67, and 75 during $1968-69 .{ }^{31}$ As has been typical in Argentine policy, the most recent devaluation and stabilization, in June 1985, began with an increase in taxes on agricultural exports to make sure that agricultural interests did not receive the full return from the rise in their product prices following the currency devaluation.

While the Argentine pattern is familiar throughout Latin America, almost the opposite is true in Asia. In Malaysia, Indonesia, Korea, Taiwan, and Thailand, the governments look to the rural sector as an important element of support. The same was historically true in Japan, and even today, the ruling Liberal Democratic party must bow to agricultural interests in maintaining high domestic prices for food. One survey of the East Asian economies has explained it this way:

In 1921, four years after the Bolshevik Revolution, V.I. Lenin instituted a program known as the "scissors" as the foundation of his "New Economic Policy." Prices for agricultural products were to be set so as to minimize the cost of living of the urban factory workers on whom Lenin depended. . . . Eastasia, with fifteen times the pressure of man on arable land [as in Russia] has not been able to afford this luxury. Not only would large portions of the population starve (in the cities first, of course), but the countryside would quickly reassert its preponderant demographic weight and "seize control of the cities" in one

30. See Henry Wallich, "The Economic Background of the Report," draft of an introduction to an edition of Paul Wallich's letters from Argentina.

31. See Richard D. Mallon with Juan V. Sourrouille, Economic Policymaking in a Conflict Society: The Argentine Case (Harvard University Press, 1975), tables 2-10, p. 55. 
fashion or another. Instead, Eastasian governments have been forced to employ what we call the "reverse scissors": a pricing policy that favors agricultural production and encourages the modernization of agriculture. At the very worst, as in China before 1949, governments have avoided excessive agricultural taxation in the interests of political harmony..$^{32}$

Other discussions of agricultural policies in specific Asian countries have also emphasized the natural political strength of the rural sector and, therefore, of the support for export promotion. ${ }^{33}$

The link between rural influence and export promotion is only the first step in the development of a successful export program. Once export-promoting policies get under way, urban-industrial exporters become their own lobbyists and eventually become the dominant political force in favor of an undervalued exchange rate, with rural interests losing their relative influence. Clearly this process is under way in Korea, where an enormous concentration of export-oriented industrialists is a strong force with regard to the exchange rate and trade policy. On the other side, after decades of import substitution in Latin America, manufacturing exporters are so weak politically as to be unable to overturn a strong currency policy, even acting in conjunction with the rural sector. Thus, the political biases of the export-promotion or importsubstitution regimes probably feed upon themselves over time, and make

32. Roy Hofheinz, Jr., and Kent E. Calder, The Eastasia Edge (Basic Books, 1982), pp. 92-93.

33. Nimit Nontapunthawat finds that "according to the Bank of Thailand, the 1973 devaluation was needed to control the huge trade deficit that had plagued Thailand since the mid-1960s. The baht value was also allowed to fall in order to keep the income (in domestic currency) of exporters and farmers from falling and to increase the competitiveness of Thai export commodities, both reasonable moves for an economy in which a high proportion of farmers' income is used to buy domestically produced goods and in which prices respond to the world market." See Nimit Nontapunthawat, "Agriculture, Thailand's Mainstay," in Laurence B. Krause and Sueo Seikiguchi, eds., Economic Interaction in the Pacific Basin (Brookings, 1980), p. 207. Brian Wawn finds that "Malaysia is aiming, not just for good overall growth in agriculture, but also for reduction in poverty as quickly as possible. It is favoured by ample land and financial resources for this. There is a strong political commitment, too, to rural Malays, who form the power base of the ruling party in the Government." See Brian Wawn, The Economies of the ASEAN Countries (St. Martin's Press, 1982), p. 58. See also Donald J. Puchala and Jane Staveley, "The Political Economy of Taiwanese Agricultural Development,"' in Raymond F. Hopkins, Donald J. Puchala, and Ross B. Talbot, eds., Food, Politics, and Agricultural Development: Case Studies in the Public Policy of Rural Modernization (Westview Press, 1979), pp. 107-31; Sopin Tongpan, "Agricultural Exports and Economic Development: A Case Study of Thailand," in Islam, Agricultural Policy in Developing Countries, pp. 240-52. 
it increasingly difficult to change course. The last section of the paper turns to some recent evidence of such difficulty.

\section{Some Observations on the Current Debate in Latin America}

Economic policymaking in Latin America has been fraught with confusion, contradiction, and frequent reversals since the onset of the debt crisis in mid-1982. Admittedly, the economic crisis has been severe, and the intellectual challenge in formulating an appropriate response is daunting. Nonetheless, it is striking how much the various governments have played for time, refusing to commit to any policy, whether one of export promotion, debt repudiation, or further import substitution. In almost every country, the trade and exchange rate policies have been contradictory and often self-defeating.

The exchange rate regime provides an excellent example. Every one of the large rescheduling countries in Latin America has allowed a significant margin to develop between a "free" rate (either in a legal parallel market or in an unofficial black market) and an official rate, as was shown in table 6. As noted, a black market premium on foreign exchange is likely to be biased against exports if import-competing prices are determined by the free rate, while export prices are set by the official rate. (As will be recalled from the table, Venezuela is an exception.) In many cases, the failure to depreciate the official rate in line with the free rate also exacerbates the problem of budget deficits. Since tariff rates on imports are governed by the official price of foreign exchange, the real value of tariff revenues can be substantially reduced by a policy that keeps the official exchange rate at a large premium relative to the black market rate.

Mexico provides an excellent case in point. After two years as the darling of the international financial community for its strong adjustment after the onset of crisis in mid-1982, Mexico aroused substantial worries about its long-term ability to overcome the crisis again in the summer of 1985, even before the disastrous earthquakes hit. The problem, very squarely, is one of exports. Most of the very sizable improvement in Mexico's external balance since 1982 has resulted from a decline in imports, rather than an increase in exports, as the following data, in billions of U.S. dollars, illustrate: 


\begin{tabular}{lrrrr} 
& \multicolumn{4}{c}{ Mexican trade } \\
\cline { 2 - 5 } & 1981 & 1982 & 1983 & 1984 \\
Exports & 19.9 & 21.2 & 22.3 & 24.1 \\
Imports & 24.0 & 14.4 & 8.5 & 11.3 \\
Trade balance & -4.1 & 6.8 & 13.8 & 12.8
\end{tabular}

Each time the Mexican government has attempted to increase economic growth, the import bill has begun to rise once again, posing a threat to debt servicing. From the first quarter of 1984 to the first quarter of 1985, imports jumped by 39 percent under the expansionary pressure of summer 1985 elections, while nonoil exports declined by 16 percent, and oil earnings abroad fell by 9 percent. Thus, the overall trade surplus for the first quarter declined from 4 billion dollars in 1984 to 2.4 billion dollars in 1985. Before the earthquakes, Mexico had announced its desire to renegotiate the terms of its multiyear rescheduling agreement, because of its need for supplementary finance at the end of 1985 . Because of the earthquakes, the need for new money is substantially greater.

The failure of exports to rise more dramatically is due in part to the continuing vacillation of the Mexican policy authorities over whether to pursue a sustained policy of export promotion. The recent vacillation, however, is nothing new, as shown by Balassa's historical survey of Mexican trade policies from 1956 to $1983 .{ }^{34}$ Until 1970, Mexico was on a path of steadily increasing trade protection, with a strong anti-export bias. Measures of effective protection of industry show a sharp upward trend between 1960 and 1970. For example, effective protection of durable consumer goods and capital goods rose from 64.6 percent in 1960 to 77.2 percent in 1970, while traditional Mexican exports showed an expected stagnation. ${ }^{35}$ Modest export incentives, introduced in 1970, lasted until the balance of payments crisis in 1976 and stimulated an increase in nontraditional exports, though from a very low base in 1970.

The policy changes after the balance of payments crisis in 1976 are somewhat reminiscent of the current policy indirection. A large currency devaluation in 1976 was combined with liberalization on imports during 1977-79. Import licensing requirements were replaced by tariffs, which were supposed to be temporary, but in fact were never removed. Plans

34. Bela Balassa, "Trade Policy in Mexico," World Development, vol. 11 (September 1983), pp. 795-811.

35. Ibid., p. 800 . 
were also made for Mexico to join the General Agreement on Tariffs and Trade (GATT). However, these plans, and indeed most of the liberalization, were dropped under the pressure of a sharp real appreciation of the peso in the late 1970s. The appreciation squeezed import-competing industries and led them to bargain, successfully, for a tightening of protection against imports. Tariff rates were increased in 1981, and when the Mexican crisis broke in mid-1982, thoroughgoing exchange controls and import licensing requirements were reintroduced.

Since late 1982, the Mexican authorities have operated with a split exchange rate system, with a controlled rate for preferential imports and all exports, and a free rate for remaining imports. During 1983 and 1984, the premium on dollars in the free market fluctuated on the order of 2030 percent, and the Bank of Mexico intervened in both the controlled and free markets to maintain a desired rate of currency depreciation. That rate has been the subject of heated debate, with protected businesses and most unions calling for a slow crawl to fight inflation and maintain low real prices for imported goods. There was a sharp real depreciation in the official currency rate at the end of 1982, but the rate of nominal depreciation vis-à-vis the dollar was not sufficient to maintain strong incentives for exporters. The recent movement in the real official exchange rate vis-à-vis the United States has been as follows (note that a decrease in the exchange rate signals a real currency appreciation):

\begin{tabular}{ccccc} 
& \multicolumn{4}{c}{ Real exchange rate $(1982: 2=1.00)$} \\
\cline { 2 - 5 } Quarter & 1982 & 1983 & 1984 & 1985 \\
1 & 0.83 & 1.21 & 1.07 & 0.93 \\
2 & 1.00 & 1.18 & 1.04 & $\ldots$ \\
3 & 1.28 & 1.16 & 1.02 & $\ldots$ \\
4 & 1.10 & 1.14 & 1.00 & $\ldots$
\end{tabular}

Thus, after a sharp depreciation in the third quarter of 1982, the currency has been allowed to appreciate to a level higher than that of mid-1982. The appreciation is even more remarkable because the peso is measured against the dollar, which has itself appreciated sharply against other currencies since 1982 .

As with exchange rate management, there has been little progress to date on export promotion via the trading system. Even with the free rates, most imports still require prior licensing, so that the system still relies heavily on exchange controls. Since the elections in the summer 
of 1985, the government has begun once again to float the suggestion of Mexico's joining the GATT. It is hard to say whether the proposal will be adopted this time and whether membership in the GATT will mean a quick reform of trading practices.

As Anne Krueger has pointed out, stabilization efforts are more likely to be costly if potential exporters believe that the government is likely to reverse any liberalization measures and to revert to protectionist "policies as usual." Krueger notes:

Reallocations will take longer and be more difficult, the greater are expectations that the realigned structure of relative prices and incentives will not continue. If it is expected that the devaluation and liberalization will be shortlived, businessmen and consumers are likely to stockpile foreign goods in anticipation of possible future reimposition of [quantitative restrictions]. In doing so, they increase the current account deficit and therefore the foreign exchange outflow required to sustain the liberalization program through the adjustment period. In the context of a situation in which foreign exchange has earlier been in excess demand because of the trade regime, increases in imports and current account deficits may stimulate further speculation against the exchange rate, in turn tending to force the reimposition of controls. ${ }^{36}$

Indeed Mexico has several times, most recently in 1976-78, embarked on a path of liberalization only to have subsequent real appreciations wipe out newly emerging exporters and policy reversals restore traditional privileges to protected industries.

The failure of governments to stick by liberalization or exportpromotion policies is of course deeply rooted in the strength of political forces allied to the import-substitution strategy. Thus, it is not surprising that the types of reversals evident in Mexico are common throughout Latin America. Corbo, de Melo, and Tybout report that the same backsliding was evident everywhere in the Southern Cone. ${ }^{37}$ Not only did the liberalizations in each case founder in a sharp subsequent overvaluation of the exchange rate, but trade liberalization measures were frequently reversed or postponed as well. The reversals created precisely the effects that Krueger pointed out. As Corbo, de Melo, and Tybout note:

An example is provided by the formal tariff reduction schedules of the government. The schedules were broken on one or several occasions when it

36. Anne O. Krueger, "Interactions Between Inflation and Trade Regime in Objectives in Stabilization Programs," in William R. Cline and Sidney Weintraub, eds., Economic Stabilization in Developing Countries (Brookings, 1981), p. 101.

37. Corbo, de Melo, and Tybout, "What Went Wrong." 
was felt that inflation was not falling fast enough. Producers reacted by delaying making major resource commitments. Such wait-and-see attitudes were confirmed by interviews with forty businessmen. The interviewees reported that they delayed taking action on government policies for periods ranging up to six months because they were uncertain whether the policy would be adhered to. ${ }^{38}$ Redundant protection proved to be another major problem in these countries. Nominal reductions in tariffs will have no effect if the reduced rates are still fully protective. In fact, given the extent of redundancy in the protective apparatus in the three Southern Cone countries in the mid-1970s, the combination of modest tariff reductions and sharp overvaluations of the currency left exporters in each of the countries as hamstrung a few years into the "liberalization" as they were at the beginning of the programs.

Developing a new export base in Latin America, it is clear, will be no easy job. What could make it next to impossible is the recent wave of protectionism in the developed economies. Most analysts have concluded that this new protectionism has not yet been severe enough to impose serious costs on exporters from developing countries. ${ }^{39} \mathrm{How}-$ ever, the risks of much stricter protectionism, particularly in the United States, are evident and must play a major role in depressing new investment in Latin American export sectors, as well as in giving political weight to groups in Latin America favoring debt repudiation and further import substitution. Increased protectionism worldwide would surely be the greatest blow to a successful resolution of the international debt crisis.

38. Ibid., p. 26.

39. See, for example, Helen Hughes and Anne O. Krueger, "Effects of Protection in Developed Countries on Developing Countries' Exports of Manufactures," in Robert E. Baldwin and Anne O. Krueger, eds., The Structure and Evolution of Recent U.S. Trade Policy (University of Chicago Press, 1984), pp. 389-418. 


\section{Comments and Discussion}

John Williamson: I have no difficulty in accepting the stylized facts laid out by Jeffrey Sachs regarding the superior performance of East Asia after the second oil shock in comparison with that of Latin America in terms both of growth and of inflation. The contrast remains valid if it is extended beyond the larger economies analyzed in the paper to cover the smaller ones as well. In recent years current account deficits, the third dimension in which macroeconomic performance is customarily measured, have actually been larger in Asia-but only because most of the Latin economies ran into debt crises, which obligated them to curb imports, so that their smaller deficits are a reflection of force majeure rather than of superior performance.

As Sachs points out, there is one notable exception to the behavior pattern in each continent. In Latin America, Colombia was a relatively high performing economy through the 1970s, and it has managed to maintain a reasonable performance and avoid rescheduling its debts so far in the 1980s. In East Asia, the Philippines is much more like a Latin American country in its stagflation and debt rescheduling. If we want to explain the different patterns, we need to explain also these exceptions, and not simply the superiority of East Asia in general.

Let me consider the various hypotheses that Sachs discusses.

First, the size of external shocks. I agree with his assessment that the severity of the shocks was not the basic difference between Asia and Latin America.' Indeed, Balassa's calculations suggest that Korea

1. I reached a similar conclusion in regard to the different Latin American countries in analyzing the results of Thomas O. Enders and Richard P. Mattione, Latin America: The Crisis of Debt and Growth (Brookings, 1984) in my paper "The External Environment and the Adjustment Process," in Khadija Haq and Carlos Massad, eds., Adjustment with Growth: A Search for an Equitable Solution (Islamabad: North South Roundtable, 1984), pp. 283-303. 
suffered external shocks that were much larger than those of any of the Latin American countries, while Thailand's shock was virtually as big as the largest Latin shock, that of Chile. ${ }^{2}$ Nevertheless, one must recognize that such comparisons are quite sensitive to the particular time periods considered; for example, even the oil exporters suffered adverse external shocks if we compare 1982-84 and 1979-81. Moreover, shocks did differ substantially from one country to another within the same region, and I argue subsequently that some of these differences were important in explaining differential performance.

A second hypothesis Sachs discusses is the extent of borrowing. He points out that Latin borrowing was not very much heavier than Asian in relation to GDP. But it was, of course, heavier in relation to exports. And since the debt-export ratio is probably the more significant indicator of creditworthiness, that does suggest a certain imprudence in policy in Latin America that was not present in East Asia.

Sachs also notes a couple of possible explanations that seem to have involved individuals fantasizing differences between Latin America and East Asia in order to rationalize their policy prejudices. The assertions that tax rates are lower and that the public sector has a lesser role in East Asia seem to me to have been buried fairly convincingly by the evidence Sachs presents.

I did not think the same was true on the question of public sector deficits. Table 7 does suggest that large public sector deficits have contributed to poor macroeconomic performance.

Finally, there is Sachs's favored hypothesis, based on the trade regime and exchange rate management: certain countries have managed exchange rates to ensure the competitiveness of industry and promote export growth, while others have not.

This hypothesis appears plausible, especially in extreme cases, such as Bolivia. In October the official exchange rate was 75,000 pesos to the dollar, while the black market rate was about a million. The only products still exported at the official exchange rate were those in which Bolivia has an extreme comparative advantage and that cannot be concealed,

2. Bela Balassa, "Adjusting to External Shocks: The Newly Industrializing Developing Economies in 1974-76 and 1979-81," World Bank Discussion Paper DRD 89 (World Bank, May 1984), table 2, and "External Shocks and Adjustment Policies in Twelve Less Developed Countries: 1974-76 and 1979-81," World Bank Discussion Paper DRD 80 (World Bank, June 1984), table 2. 
namely natural gas and metals. Since natural gas cannot be stockpiled, it was still being exported normally, but even metal ores were being delayed until the next devaluation of the official rate. The inefficiencies and arbitrary rents that result from such arrangements are massivethough smaller now than they were several years ago, before the economy had adjusted to the need for a major real devaluation and started to buy two-thirds of its imports at the parallel rate. The incentive to produce nontraditional, nonconcealable exports is nonexistent.

Unfortunately, it is easier to establish the plausibility of this case than to demonstrate it statistically. The most satisfactory evidence comes from the estimates of effective protection by Balassa and others, but these data relate to the $1960 \mathrm{~s}$. The data on black market premiums shown in table 6 also provide relevant, though far from perfect, evidence. For example, Venezuela pursued extremely inward-looking policies in the period 1977-81 even though the black market premium was negligible, as a result of the abundant supply of foreign exchange from petroleum exports. The statistics on real exchange rates shown in the first column of table 6 are even less revealing, partly because they show appreciation in bilateral rather than effective exchange rates, and partly because they show appreciation relative to an arbitrary base period rather than overvaluation relative to some persuasive concept of equilibrium.

Despite the inadequacies of the evidence, it suffices to establish that East Asia has been more outward-looking than Latin America. The trade bias hypothesis can also explain the outliers, Colombia and the Philippines; Colombia was probably more outward-looking than most Latin American countries, and the Philippines more inward-looking than most East Asian countries. The hypothesis cannot, however, explain everything. In particular, Chile adopted extreme outward-looking policies in the late 1970s, but nonetheless encountered a severe crisis in the 1980s. The proximate reason was the decision to freeze the exchange rate in the hope of combating inflation, which led to extreme overvaluation.

I am less convinced by the paper's explanation of differences in the trade regime as a function of differences in the interests of the dominant class. The comparison of the distributional effects of exchange rate devaluation and import controls is entirely unexceptional; indeed, it is conventionally employed by the International Monetary Fund to justify its preference for devaluation. But it is not obvious that one can legitimately measure the political power of rural interests by the size of 
the rural population; if that were true, the European Community would not spend most of its revenue on the Common Agricultural Policy. Nor does the political difficulty in Latin America of imposing explicit export taxes on agricultural commodities that Sachs correctly alludes to seem consistent with the hypothesis of a politically weak rural class. Nor can I easily reconcile this hypothesis with the massive size-over 3 percent of GNP - of the credit subsidies paid to the agricultural sector in Brazil before the involvement of the IMF.

To my mind a more convincing explanation than class conspiracy is provided by the simpler hypothesis of policy errors: that is, decisions that would have been made differently had policymakers been in full command of the facts and taken a long-term view. The initial impetus for import substitution came from a faulty analysis that underestimated its costs and overestimated the obstacles to export promotion. More recent errors have, in my view, stemmed primarily from a factor often overlooked in the profession, except in the specialized literature on the political business cycle: myopia, political reluctance to accept shortterm costs in the expectation of longer run gains. Mexico, which used the transitory income of the 1979-81 oil boom to go out and borrow from the banks so as to raise absorption by even more than income, provides an extreme example. But all the Latin countries Sachs discusses except Colombia have at times allowed overvaluation to emerge in the hope that it would provide a quick fix solution to inflation (Brazil did so only in 1980). Colombia is the exceptional case in Latin America: it attempted to live by the permanent income hypothesis during the export boom of the late 1970s, dampened the business cycle by running large budget and trade surpluses, accumulating reserves, and refusing to borrow from the banks, and even tried, though without complete success, to resist real appreciation in defense of its nontraditional export industries. Myopia can also explain the resort to deficit financing and the excessive foreign borrowing that, as already argued, contributed to Latin America's poor performance.

Thus, my basic explanation of differential performance would run in terms of the farsightedness of policy formation, with an exchange-rate policy dedicated to the preservation of competitiveness and outwardoriented trade policies as particular manifestations of less myopic policies. I certainly believe this explains the happier experience of Colombia in comparison with that of Argentina, Chile, Mexico, and 
Venezuela. Myopia also contributed to Brazil's problems: the pharaonic investment projects of the military era, the attempt to prolong miraculous rates of growth into the era of high oil prices, the decision to fight inflation by prefixing indexation in 1980 , and the expansionary policies that led to the unsustainable boom of that year. Nevertheless, Brazil did for the most part pay attention to securing a competitive exchange rate and might just have escaped the need to reschedule, had it been located in Asia and therefore not been subject to the problem of contagion-a phenomenon that Sachs overlooks.

My impression is that on the whole the Asian countries have been less myopic. Malaysia is another country, like Colombia, that resisted the siren calls of the banks to lend it money when none was needed. Thailand also seems to have been relatively well managed. Korea, it is true, got close to the brink in 1980 as a result of overexpansionary policies in 1979 and large external shocks; had it been in South America and therefore subject to contagion, it might well have succumbed. Indonesia was probably saved by its positive external shock. The Philippines did not have that benefit, so it got into trouble like Latin America.

If one has to pick one stylized set of facts to account for the differing experiences of Latin America and East Asia, then I agree with Sachs that the trade regime and exchange rate policy hypothesis is the most plausible candidate. Nevertheless, one must note that the competing hypothesis that runs in terms of the work ethic, educational attainment, and entrepreneurial motivation has not been considered; that outwardoriented trade regimes and competitive exchange rates do not necessarily go together, as illustrated most clearly by Chile; and that the extent of myopia helps explain both the trade regime and other factors that have contributed to poor performance.

It may be useful to add a brief explanation as to why openness per se, and not simply the size of the export surplus, should be a relevant factor in determining performance. A country with a very small trade sector generally has a limited range of exports based on resource-intensive products that are exploiting some local comparative advantage bestowed by geology or climate. These products tend to exhibit both inelastic supply and inelastic demand, so there is a very little possibility of export expansion at the margin. Import capacity tends to be entirely preempted in importing intermediate goods, including oil, that are necessary to keep 
industry going for the domestic market. Hence, there is minimal elasticity in the trade structure to permit adjustment to trade shocks. This is the basic, though not the only, reason why the size of the trade sector is significant in enabling countries to overcome external shocks.

Finally, I want to challenge Jeffrey Sachs's assertion that policies since 1982 in "almost every country" in Latin America have been "contradictory and often self-defeating" and lacking any clear sense of direction. On the contrary, I think there is a widespread acceptance of the need to move to export promotion. All seven of Sachs's countries undertook major real devaluations after 1982. Four of the seven have not allowed any significant slippage since their first major devaluation. Peru, Mexico, and Venezuela have all slipped badly at some point, but all have made subsequent corrections, at least partially.

The case against import controls as a way of life, which is what Sachs attacks in the body of his paper, is vastly stronger than the case against their use as a temporary, emergency response to a balance of payments crisis, which is what he complains of in the concluding section. It is vitally important not to encourage new investment in inefficient importcompeting industries, but instead to promote exports of goods that enjoy a real comparative advantage. But replacing imports by a fuller utilization of existing domestic capacity can often be a sensible short-run policy, and the quickest way of achieving that may well involve the use of import controls. Europe did not begin postwar reconstruction in 1946 by liberalizing its imports against the dollar area; it liberalized as and when the recovery of the balance of payments permitted. I would recommend the same strategy to Latin America today. Similarly, no country should plan to live with a permanent premium on the black market exchange rate. But as a response to a loss of confidence, while action to promote exports is being implemented, a premium on the parallel rate may conceivably be less damaging than an overshooting of the official rate.

In my judgment the biggest obstacle to export promotion in Latin America today is the level of real interest rates rather than exchange rate or trade policy. It is difficult to envisage much of a boom in investment in export industry with real borrowing costs in the range of 30 percent or more, even with highly competitive exchange rates. 


\section{General Discussion}

Lawrence Krause agreed with Jeffrey Sachs that the outward-looking versus inward-looking distinction is an important one for understanding countries' macroeconomic performance and debt experience, but he added that this distinction ought to encompass more than trade and exchange rate policies. Robert Gordon pointed to apparent cultural differences between Latin American and Asian countries and to the concern of American firms with the political stability of the countries in which they build overseas plants as two other factors that may have contributed to the growth in the Asian countries' export sectors.

On the question of whether the Latin American countries have suffered more severe external shocks than the Asian countries, Richard Cooper noted that shifting the base and terminal years used for comparison by even a year or two can affect whether terms of trade facing a particular country appear to have deteriorated or improved. For example, table 2 shows that Brazil's terms of trade deteriorated markedly between 1979 and 1983, but 1979 was a year with high coffee prices; the picture would look somewhat different if one compared 1980 with 1983. William Cline argued that the terms-of-trade comparison in table 2 is misleading, insofar as the net improvement in the oil exporters' terms of trade from 1979 to 1983 reflects a surge and subsequent collapse in oil prices that had a much different impact on Mexico and Venezuela than a smooth upward trend in the terms of trade would have had. Sachs countered that the failure of Mexico and Venezuela to treat the oil price increases during the early part of the 1979 to 1983 period as largely temporary, not the fact that prices rose and then fell, was what got them into trouble. Cline also suggested that the magnitude of terms-of-trade and interest rate shocks should be judged against a country's export base rather than against GDP, since the export base is the debt-servicing capacity base.

Much of the discussion focused on the relative degree of government interference in the economies of Latin America and Asia. George von Furstenberg argued that comparisons of tax revenue-GDP ratios across countries are uninformative; comparisons of marginal tax rates across countries would be meaningful, but the average tax rate is not a good proxy for the marginal tax rate. Cooper cited the situation in Indonesia 
some fifteen years ago as a good example of a high marginal tax rate not translating into high tax revenues. At that time Indonesia had a very high tariff but almost no tariff revenues because the high tariff encouraged widespread smuggling and evasion. The tariff rate has since been lowered, and tariff revenues have gone up. Cooper also noted that oil royalties make up a significant fraction of the revenue collections in Indonesia, Malaysia, Mexico, and Venezuela, and that these revenues are quite different in character from other tax revenues. Von Furstenberg suggested that some forms of hidden taxation-for example, real wage legislation in Argentina that could be considered in effect a tax on producers-might be more invidious in Latin America than in Asia.

In William Branson's view, evidence that government deficits have grown more rapidly in debt-rescheduling countries is not necessarily evidence of a larger government role in their economies; an equally plausible interpretation is that countries that tried to avoid the effects of the oil shocks by fiscal expansion got themselves into trouble. Cooper suggested that a distinction ought to be drawn between increases in the deficit attributable to spending on, for example, quasi-governmental enterprises and increases attributable to increased debt service.

Von Furstenberg cited as a historical precedent for rural interests favoring export-oriented policies the conflict between the free-trade South and the protectionist North during the antebellum period in the United States. Several other participants expressed skepticism about this explanation of the export orientation of Asian policies. Gordon found the predicted differences in the shares of GDP going to various interest groups under alternative exchange rate policy regimes surprisingly small relative to, for example, the rather large changes in labor versus nonlabor income in European countries that Sachs has found in earlier work, and questioned whether the differences were large enough to call forth a political polarization of the sort Sachs hypothesizes. Krause did not find the argument that rural interests have enjoyed greater political power in Asia than in Latin America fully persuasive; he suggested Taiwan as a country that did not fit this generalization. Krause also suggested that more attention be given to the role of historical accident and demonstration effects in the policy determination process. Gordon noted two additional factors that might deserve some discussion in connection with the formation of Latin American trade and exchange rate policies: first, the role of long-standing mistrust of the United States 
in motivating policies that would keep out U.S. products; and second, the severity of Latin American inflation, which might have motivated some policymakers to advocate overvaluation as an anti-inflationary tactic.

Cline seconded John Williamson's disagreement, expressed in his formal comments, with the view that the Latin American countries have done little but play for time since the debt crisis hit. In Cline's assessment, they have taken significant steps to deal with the situation. For example, Mexico devalued the peso by more than one-third from 1981 to 1983 (although it allowed some subsequent real appreciation before new devaluation in July 1985). Similarly, after the debt crisis broke, Brazil devalued its currency rate by 20 percent and Argentina devalued by 40 percent. All three countries have cut fiscal deficits relative to GDP, although further cuts remain necessary. 